\title{
Geochemical Processes Leading to Variation of Soil Development on Calcareous Toposequence in Semiarid Fields
}

Pelin Alaboz ( $\sim$ pelinalaboz@isparta.edu.tr)

Isparta University of Applied Sciences https://orcid.org/0000-0001-7345-938X

Hüseyin Şenol

Isparta University of Applied Sciences

Orhan Dengiz

Ondokuz Mayis University

\section{Research Article}

Keywords: clay mineralogy, soil physics, weathering indices, vertisol, cambisol, leptosol

Posted Date: October 25th, 2021

DOI: https://doi.org/10.21203/rs.3.rs-1011759/v1

License: (c) This work is licensed under a Creative Commons Attribution 4.0 International License.

Read Full License 


\title{
Geochemical Processes Leading to Variation of Soil Development on Calcareous Toposequence in Semiarid Fields
}

\author{
Pelin Alaboz $^{1^{*}} \quad$ Hüseyin Şenol ${ }^{1} \quad$ Orhan Dengiz $^{2}$ \\ ${ }^{1}$ Isparta University of Applied Sciences, Faculty of Agriculture, Department of Soil Science \\ and Plant Nutrition, Isparta, Turkey \\ ${ }^{2}$ Ondokuz Mayıs University, Faculty of Agriculture, Department of Soil Science and Plant \\ Nutrition, Samsun, Turkey \\ *Corresponding author e-mail: pelinalaboz@isparta.edu.tr
}

\begin{abstract}
This study was carried out in soils formed in different physiographic units (summit(PI), shoulder(PII), backslope(PIII), footslope(PIV)) on the limestone parent material under the same climatic conditions. The study was assessed clay mineralogy, weathering indices, mass loss/gain states, and physicochemical properties of different profiles with limestone parent material. It is concluded that smectite clay mineral is dominant in the footslope unit (PIV), with differences in clay mineralogies due to physiographic change. The highest aggregate stability $(63.74 \%)$ was determined in the in situ physiographic summit unit. The soil's field capacity and wilting point contents showed statistically significant changes with the increase in smectite minerals and clay in the PIV profile on the footslope unit $(\mathrm{p}<0.01)$. A positive $(0.506 ; \mathrm{p}<0.05)$ correlation was found between the variability in physiographic units (from Summit to footslope) and the available water content (AWC). Bulk density and porosity characteristics varied depending on the particle size distribution and the type of land use. The soils formed in shoulder and backslope units, which are in the Entisol soil class, are classified as "not decomposed" according to the Chemical Alteration Index (CIA), Chemical
\end{abstract}


Weathering Index (CIW), and Plagioclase Alteration Index (PIA) values. In the Inceptisol and Vertisol ordo, it was determined that the basic cations were leached in the PI and PIV profiles in the summit and footslope units, and the separation was more advanced. The highest losses from the soil were obtained from the backslope, while the gains were obtained from the footslope physiographic unit. As a result of this study, it has been revealed that soil formation in the summit and bottom lands (footslope) is more effective than other physiographic units, and physicochemical properties are affected by these processes.

Keywords: clay mineralogy, soil physics, weathering indices, vertisol, cambisol, leptosol

\section{INTRODUCTION}

In general, soil is the name given to the earth's crust due to geochemical events and biological activities during the physical and chemical decomposition of organic and inorganic materials. Additionally, soil forms an integral part of the terrestrial ecosystem and ecosystem services. Its non-static, dynamic nature and unique balance between the system's physical, chemical, and biological components.

For the first time, Dokuchaev and later Hilgard revealed that different soils were formed under other environmental conditions, particularly with different climate and vegetation effects from a particular parent material (Dengiz and Senol, 2018). Joffe (1949) distinguished two types of soil formation factors, active and passive. He stated that passive soil formation factors only symbolize the substances that serve as the source of the mass and the conditions that affect the mass; these are the parent material, topography, and the passing process. He stated that active soil formation factors are the essential materials for soil formation and the means that provide energy affecting the mass and that organisms, climate, and partially the hydrosphere symbolize the soil formation factors in this class. Soil forming were explained by Simonsen (1959) as accumulation events in the soil (organic matter accumulation, new 
sedimentation), the transformation of soil parent materials, displacements in soil, events that prevent horizonization (clay leaching), and losses from the soil (leaching, erosion, etc.). In addition, White (2013) and Tuncay et al. (2019) stated that topographic factors mainly affect soil formation by altering the amount of water entering the soil profile, soil temperature, and erosion-transport and accumulation on the surface.

When parent material decomposes under the influence of environmental factors, the components present in their structure are released. According to the ecological conditions, it is known that many soil properties such as color, structure, permeability, plant nutrients vary according to these substances released as a result of decomposition (Mandel and Bettis, 2001; Schaetzl and Anderson, 2005; Dengiz et al. 2013). For instance, impermeable soil can be formed on the clayey-calcareous parent material, while dark-colored soils rich in plant nutrients occur on the basalt parent material (Young, 2012). Again, according to Pal et al. (2014), while Alfisol, Inseptisol, Entisol, and Mollisol soils are formed in granite-gneiss, calcic-gneiss parent materials in hot, semi-arid ecosystems, on the other hand, they stated that Mollisol and Alfisol soils formed on the parent materials such as limestone, micaceous sandstone in hot, humid ecosystems with $3000 \mathrm{~mm}$ rainfall.

Dengiz and Baskan (2010), Saricaoglu et al. (2020) declared that topography is an essential factor in explaining the different character of soils and their formation, as well as the primary material, particularly in the local or small area. In this context, the researchers stated that the topographical elements, especially the slope, slope length, and slope direction parameters, cause microclimate, vegetation, and soil differences. Furthermore, they stated that soil erosion in the local area causes soil formation processes and differentiation by affecting the difference in speed and size depending on the degree of slope.

Mineral weathering, an essential part of the pediatric assessment, plays a vital role by transforming bedrock into decomposed parent material and soil that provides nutrients to 
ecosystems. In this case, during decomposition, the released elements are leached or accumulated according to ambient conditions due to various pedogenic processes (Lybrand and Rasmussen 2018; Tuncay et al. 2020). Among these processes, functions such as dissolution of primary minerals, formation of secondary minerals, redox reactions, transport of some materials, and ion exchange can occur. Especially the dominant secondary minerals of soils are clay minerals formed due to chemical changes of primary minerals. The amount and type of clay in the soil affect many of the soil's physical and chemical properties. In a study investigating the underlying soil formation stages in a glacial ecosystem (Mavris et al., 2010), it was determined that the coarse material decreased with physical decomposition, and the decomposition caused acidification by increasing the clay fraction. Clay minerals with a 2: 1 layered lattice structure, such as Montmorillonite, are characterized by a large specific surface area and high load, which increases water retention and cation exchange capacity (Fissore et al., 2016).

Moreover, the effects of Smectite clay mineral on the micro-aggregate formation (Fernández-Ugalde et al., 2012) and studies have shown that the type of clay minerals is essential in the stability of soils (Morgan, 2005). Again, Aboudi Mana et al. (2017) determined the permeability due to the pore structure of soils dominated by argillaceous minerals at low levels. Yilmaz et al. (2014), while large-scale aggregation occurs in kaolinitic soils, montmorillonite soils' stability was low. By Moghimi et al. (2012), the adequate properties for water-resistant aggregates were determined as organic carbon, kaolinite clay mineral, and $\mathrm{Ca}^{2+}$. Jones (1983) stated that in soils with a high swelling shrinkage rate depending on the clay type, root penetration resistance due to bulk density is low; Narloch et al. (2020) stated that while compressibility decreases in soils dominated by montmorillonite clay, it increases in soils dominated by kaolinite clay. 
For many years, it has been known that the changes of soils in the period for soil formation vary considerably depending on environmental characteristics. These changes involve mineral fragmentation, biological weathering, interactions, geochemical changes of elements and cycles in the soil plant-water system. Individual decomposition rates of soils vary due to changes in soil properties and differences in environmental conditions. Accordingly, soils are a complex system formed due to different combinations of factors that make soil. Today, there are two distinct approaches in characterizing soils and rocks in chemical weathering. The first is the fluid aqueous environment's geochemical properties (Aiuppa et al., 2000; Phillips and Rojataczer, 2001). The second approach is the weathering indices applied to determine the weathered profile's geochemical and mineralogical properties and study soils' weathering processes by digitizing (Chesworth et al., 1981; White, 1983; Nesbitt and Wilson, 1992). There are some losses, gains, and transformations during the pedogenic processes in soil formation. Mass change indices such as chemical alteration index (CIA), plagioclase alteration index (PIA) base/sesquioxide index $\left(\mathrm{R}_{2} \mathrm{O}_{3}\right)$, in which the phenomena occurring within the specified processes are quantified, leaching, the state of chemical components or clay minerals reveal the decomposition of soils and their behavior during the process. (Egli et al., 2001, 2003; Gunal et al., 2011). Partition indices are traditionally calculated using different formulas using the molecular ratios of the significant element oxides. The stoichiometric change of important element oxides during decomposition occurs in index values. Each oxide's molecular ratio can be easily calculated using the weight percentage of their oxides in question. Chemical weathering indices, sometimes termed alteration indices, are often used to characterize dissociative profiles. Tuncay et al. (2020) stated that the topography changes under the same climate significantly affect the soil's physical and chemical properties, and the CIA and CIW also revealed this change. Ozaytekin and Dedeoglu (2021) reported that the weathering index values were distributed following the 
geological age in their study on the soils' weathering rates and mass balance formed on the Hasandag volcanic material.

This study aimed to examine the pedogenetic changes of Entisol, Inceptisol, and Vertisol soils with different development levels on the same land cover and the same parent material (limestone-marl) semi-arid ecological conditions, considering the weathering indexes, geochemical-chemical events, and mineralogical data.

\section{MATERIAL AND METHODS}

\section{Field description of the study area}

The study area covers an area that includes the Sandikli district and its immediate surroundings, located within the provincial borders of Afyon (Figure 1). Sandikli district and the areas around it have a height of 1000-1200 m. The dominant geological materials spread in the study area are sedimentary rocks consisting of conglomerate, claystone, limestone, and sandstone (MTA, 2011).

When the study area's long years of climate data are examined, the average temperature is $10.8^{\circ} \mathrm{C}$, the annual precipitation is $362.40 \mathrm{~mm}$, and the annual evaporation is $663.08 \mathrm{~mm}$. The continental climate is dominant, with cold winters and hot and dry summers. According to Soil Survey Staff (2014), soil temperature and humidity regimes are examined when the soil temperature regime is Mesic, and the moisture regime is Xeric. Additionally, according to the Newhall model, Dry Xeric was determined as a subgroup of soil moisture regime (Newhall and Berdanier, 1994; Van Wambeke, 2000). 


\section{Soil and rock sampling}

Within the study's scope, soil and rock sampling were carried out in four different soil profiles formed on the limestone base material representing different topographic positions in the section located in the northeast-southwest area. Soil profiles are located on the summit (PI), shoulder (PII), backslope (PIII), and footslope (PIV) physiographic units, respectively (Figure 2).

The sampling points were evaluated on the geology and topographic map, profile pits were dug in the study area, and soil sampling was made from each profile. Disturbed and undisturbed soil samples were taken from the profiles based on the horizon, and the morphological definitions of the profiles were created. According to Soil Survey Staff (1993), profile definitions are made, naming and classifying horizons according to Soil Taxonomy (2014).

\section{Geo-chemical and mass balance analysis}

The soil made air dry was passed through a $2 \mathrm{~mm}$ sieve to determine some physicochemical soil properties. The sand, silt, and clay contents (\%) were determined by the Bouyoucos hydrometer method (Bouyoucos, 1951), soil color in dry and moist condition using Munsel color scale according to Soil survey staff (1993). Electrical conductivity (EC) and soil reaction $(\mathrm{pH})$ were measured in a 1: 1 soil-water suspension (Soil Survey Staff, 2014). Additionally, $\mathrm{CaCO}_{3}$ content of soils, exchangeable cations with ammonium acetate $\left(\mathrm{Mg}^{++}, \mathrm{Ca}^{++}, \mathrm{Na}^{+}\right.$ve $\left.\mathrm{K}^{+}\right)$, organic matter content (Soil Survey Staff, 2014), moisture constants (Klute 1986), and wet aggregate stability (Kemper ve Rosenau, 1986) were determined. Cation exchange capacity (CEC) values were found by saturating soils with Na-acetate, then extracting with ammonium acetate and reading the extracted sodium in atomic absorption 
spectrophotometer (Richards, 1954; Anonymous, 1973). The wet sieving method (with a single sieve diameter) recommended by Kemper and Rosenau (1986) was used for the wet aggregate stability analysis. Moisture constants were determined with ceramic table $\mathrm{pF}$ set (U.S.A, Soil Moisture Equipment Corp.) (Soil Survey Staff, 2014).

For a comprehensive analysis, dried ground soil and rock samples $(\Phi<38 \mu \mathrm{m})$ were extracted according to Chao and Sanzolone (1992) and made ready for analysis. According to Perkin Elmer (1973), free $\mathrm{Fe}_{2} \mathrm{O}_{3}$ and $\mathrm{Al}_{2} \mathrm{O}_{3}$ major elements were determined in the ICP-OES device.

Chemical Alteration Index (CIA), Chemical Weathering Index (CIW), Plagioclase Alteration Index (PIA), Bases/ $\mathrm{R}_{2} \mathrm{O}_{3}$ values were determined by Equations $1,2,3$, and 4, respectively.

- $\mathrm{CIA}=(100)\left[\mathrm{Al}_{2} \mathrm{O}_{3} /\left(\mathrm{Al}_{2} \mathrm{O}_{3}+\mathrm{CaO}+\mathrm{Na}_{2} \mathrm{O}+\mathrm{K}_{2} \mathrm{O}\right)\right](\mathrm{Nesbitt}$ ve Young, 1989)

- $\mathrm{CIW}=(100)\left[\mathrm{Al}_{2} \mathrm{O}_{3} /\left(\mathrm{Al}_{2} \mathrm{O}_{3}+\mathrm{CaO}+\mathrm{Na}_{2} \mathrm{O}\right)\right]$ (Harnois, 1988)

- PIA = (100) $\left(\mathrm{Al}_{2} \mathrm{O}_{3}-\mathrm{K}_{2} \mathrm{O}\right) /\left(\mathrm{Al}_{2} \mathrm{O}_{3}+\mathrm{CaO}+\mathrm{Na}_{2} \mathrm{O}+\mathrm{K}_{2} \mathrm{O}\right)$ (Fedo et al., 1995)

- Bases $/ \mathrm{R}_{2} \mathrm{O}_{3}=\left(\mathrm{MgO}+\mathrm{CaO}+\mathrm{Na}_{2} \mathrm{O}+\mathrm{K}_{2} \mathrm{O}\right) /\left(\mathrm{TiO}_{2}+\mathrm{Fe}_{2} \mathrm{O}_{3}+\mathrm{Al}_{2} \mathrm{O}_{3}\right)$ (Birkeland, 1999) (Eq.4)

Major elements change rates (vertical movements) and accordingly enrichment factors (with the formula below) were determined.

$\% \mathrm{EF}($ Enrichment factor $)=[(\mathrm{Xi} / \mathrm{Mi}) /(\mathrm{Xr} / \mathrm{Mr})-1] \mathrm{x} 100$

In the formula,

$\mathrm{Xi}$ : mobile element concentration in the horizon

Mi: Reference element concentration in the horizon

$\mathrm{Xr}$ : mobile element concentration in the parent material 
Mr: By determining the reference element concentration in the parent material, the relationships between the ages of the studied soils and the time and weathering rates have been revealed using the geochemical indices given above.

If the standardized volumetric range coefficient is rewritten using immobile elements such as Ti or Zr:

$$
\varepsilon_{i w}=\left(\frac{P_{p} C_{\mathrm{T}_{i} p}}{P_{w} C_{\mathrm{T}_{i} w}}\right)-1
$$

Chadwick et al. (1990) formulated open system mass transport function (T).

Substituting $\varepsilon$ in this formula for:

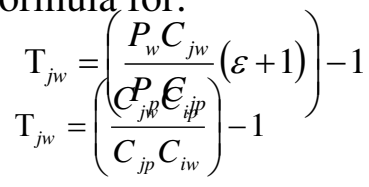

Tjw: Open system mass transport function

Cjw: Element concentration in the horizon

Cjp: Element concentration in the parent material $(\mathrm{kg} / \mathrm{ton})$

Cip: Index element concentration in the parent material

Ciw: index element concentration in the horizon

The mass motion in any horizon is:

$$
M_{j f l u x}=P_{p} \times \Delta z_{w} \frac{1}{\varepsilon+1} C_{j p} \times \mathrm{T}_{j w}
$$

Mjflux: Elemental movement in the horizon $\left(\mathrm{g} \mathrm{cm}^{2}\right)$ 
Pp: volume weight of parent material

$\Delta \mathrm{Zw}$ : Horizon thickness (m)

$\frac{1}{\varepsilon}+1:$ Standardized volumetric mass coefficient

Cjp: elemental concentration of parent material

Tjw: Open system mass transport function

The formula in question is for the entire profile

$$
M_{j f l u x(z w)}=\sum_{\alpha=1}^{\wedge} C_{j p} P_{p}\left(\frac{1}{\varepsilon+1}\right) \mathrm{T}_{j w} \Delta z
$$

If $\mathrm{M}_{\mathrm{jflux}}$ is negative, it indicates loss from the system; if it is positive, it indicates participation in the system. If the beginning of soil formation is known, the annual decomposition rate is resolved by dividing the value found by the previous year.

\section{Primer and seconder mineralogical and thin section analysis}

The proportional distribution and degrees of the abundance of primary minerals in ground samples were determined by an X-ray diffractometer $\left(2 \theta=2-70^{\circ}\right)$ (Jackson, 1963). To determine the clay mineral type, leaching, decantation, lime removal, centrifugation, and sedimentation processes. The resulting clay fractions were separately saturated with $1 \mathrm{~N}$ $\mathrm{MgCl}$, and $\mathrm{KCl}$ leached and plated. In obtaining XRD peaks, the air dry and potassium 550 ${ }^{\circ} \mathrm{C}$, in part saturated with potassium, air dry in the parts saturated with magnesium, and magnesium was made after 16 hours in ethylene glycol steam in the desiccator at $60{ }^{\circ} \mathrm{C}$. Clay

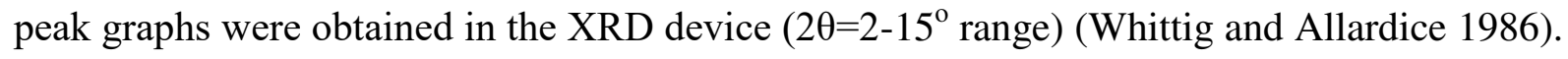
The textures of minerals and rocks with thin sections were determined by photographing them under the microscope (Murphy et al., 1977). 


\section{Statistical analysis}

Significance levels of changes in soil properties were determined by applying the TUKEY's multiple comparison test. Evaluations were made using the ANOVA menu in Minitab 17v. Package program.

\section{RESULTS AND DISCUSSION}

\section{Some physicochemical and morphological characteristics of soils}

Morphological descriptions of the horizon belonging to the soil profiles included in the study are given in Table 1, and their images are shown in Figure 3. The PI profile formed on the physiographic summit unit was classified as Typic Haplustept. The PI profile has A-BwC defining horizons. it has been ranked as Typic Haplxerept in the Inceptisol ordinance since it shows an advanced soil formation than Entisols and it has diagnostic horizon (cambic) depending on the structural development. The PII soil profile was classified in the Lithic Xereorthent subgroup and was determined by the Entisol ordo since it does not contain a subdiagnosis horizon. As the physiographic unit, the profile grouped as Shoulder has an A/C horizon sequence. Backslope is classified in the Entisol order in the PIII profile located on the physiographic unit. These soils located on sloping lands are shallow soils that do not have enough pedogenetic processes due to exposure to erosion, especially since enough vegetation does not cover them. They are classified in the Lithic Xereorthent sub ordinance. Its profile coded as PIV is located on the footslope physiographic unit and classified as Typic Haplustert. These soils are deep and heavy textured soils with high clay content and have Ap/Ad2/Bss/C horizon sequences.

Profile horizons, designated PI, have a clay loam and clay texture, with a moderate, medium granular structure, plastic when moist and slightly hard when dry. Soils covered with pasture cover, formed on limestone parent material. The PII profile horizons' bodies are 
clayey loam on the surface, silty clay, and silty clay loam to the deep; the surface is covered with pasture vegetation, the primary material is limestone. PIII profile also has a texture of clay loam and granular structure development in the surface horizon and the darker color on the surface; the color gets lighter as the profile approaches towards the parent material, depending on the lime increase. The color in the profile surface horizon, symbolized by PIV, is $5 \mathrm{YR} 4 / 2$ in dry conditions and $5 \mathrm{YR} 3 / 2$ in humid conditions. This situation continues homogeneously within the profile. Although clay loam is in the texture surface horizons, it turns into a clay structure due to the clay ratio increasing towards the depths. Soils with granular structure in A horizons, semi-angular block structures have occurred in deeper areas. Primarily, there are widespread and small slickenside formations in $49-78 \mathrm{~cm}$ depth, which is one of the critical indicators of vertisol soils. Its main material is limestone and colluvial deposit.

In local areas with high topographic differences and similar main material-bedrock and similar land cover-use at short distances, the landform and different topographic positions significantly impact the soils' formation and development processes. Even if the climatic conditions are the same in a region, it has been stated by the researchers that a significant change in the topography may cause the formation of different soils. In this context, Sağlam and Dengiz (2015) found that the soil formed in the bottom land position and the fine materials brought by the waters from the sloping lands are deep, rich in clay, and have low permeability. The contribution of different main materials' physical, chemical, and mineralogical properties causes local soil formation differences. Therefore, although the region's topographical conditions and geological diversity have the same climate, diverse soils have been formed under different drainage conditions. In the study conducted by Dengiz and Baskan (2010) to determine the relationship between soil profile development and land formdifferent topographic position, it was determined that topographic positions in the formation 
of soils affect the morphological, physical, and chemical properties of soils. Thus, it is thought that the slope degree is one of the essential factors affecting the soil formation process in the soil profiles on the slope lands. Again, Sommer et al. (2008) reported that depending on the geomorphological situation and spatially changing soil erosion, some parts of the land will erode faster than others. Therefore, soil development will be different.

Some physicochemical properties of the soils belonging to the study area are given in Table 2. The soil profiles' $\mathrm{pH}$ level is a slightly alkaline reaction, and the salinity problem has not been determined. The change in EC content was primarily defined in the PIV profile, the footslope physiographic unit. At the $\mathrm{pH}$ level, the difference was determined in PII and PIII profiles, which have the narrowest shoulder and backslope physiographic units. Lime content in the horizons varied significantly, and the highest value was determined in the PIII profile on the backslope. In contrast, the lower lime content was determined in the PI and PIV profiles with higher soil formation. The reason for low levels of $\mathrm{CaCO}_{3}$ in these soils is that lime is transported from the profile by leaching.

On the other hand, the narrow range of PII and PIII soil properties' variation and the high levels of lime content have emerged due to insufficient water penetration from the physiographic unit into the profile. Tuğyan and Sungur (2020) determined the lime content of soils formed on limestone at low levels in the range of $0.79-1.58 \%$ and reported that the reason for this lowness was leaching. While organic material is at a high level in surface horizons in all profiles, it has significantly changed lower horizons. Especially in PII and PIII profile horizons, there is a 2-fold decrease as they descend from the surface. The presence of a horizon with a physical root boundary below the A horizon in the PIV profile has prevented OM's transition to sub-horizons, especially. Also, organic matter varied more in PI and PIV profiles. The clay contents of the profiles were determined between 5.02-41.14\%. The soils' 
clay content was determined in the highest PIV profile and showed similar distribution with other profiles except for PII.

On the other hand, the rate of sand is the opposite. Although clay particles are easily transported when eroded, as a feature of their size and bulk density, corrosion is more complex than other particles (Hudson, 1995). Dengiz and Baskan (2010) stated that soils' physical and chemical properties vary depending on environmental factors such as land cover, topography, and parent material. The soils' clay content is high (except PII), and it has been determined that they are at a higher rate in lower horizons than in surface horizons. This event is considered an indicator of leaching. The cation exchange capacity of soils was determined between 8.21-30.53 $\mathrm{cmokg}^{-1}$. Among these cations, especially extractable Ca (21.43-40.17 $\left.\mathrm{cmokg}^{-1}\right)$, and $\mathrm{Mg}\left(0.22-7.48 \mathrm{cmokg}^{-1}\right)$ cations form the majority of extractable cations due to the dissolution of carbonates, while $\mathrm{K}\left(0.05-1.08 \mathrm{cmokg}^{-1}\right)$ and $\mathrm{Na}\left(0.02-0.24 \mathrm{cmokg}^{-1}\right)$ ions were detected at low levels.

Mineralogy of rock and clay

The representative rock-thin section microscope image of the soils formed on the limestone parent material is shown in Figure 4. PII and PIV profile rocks are litharenite composed of quartz, sparse plagioclase, mica, and rock fragments interconnected with carbonate cement. Quartz crystals are randomly distributed in the rock and makeup about 25$30 \%$. Since plagioclases become clayed with the effect of weathering, their twinning has disappeared or become less pronounced. The rock fragments that make up the main percentage of the rock are composed of pieces of rocks such as limestone, mudstone, siltstone, shale, chert, sandstone, quartzite, and schist. However, limestone fragments are denser. Both the minerals and rock fragments that make up the rock are almost equal in size. Since the fractures and cracks developed in the rock are filled with iron formations, they are seen in blackish and brownish color distribution. 
PI and PIII profile rocks are sharply fractured, dark gray, calcite veined limestone with intense fractures and cracks (Figure 4). The rock, which has a micritic texture, consists of very thin intraclass and scarce fossils. The rock has melting cavities with many broken fissures, and these are filled with spar calcites. Calcites are medium to small sizes and crystallized interlocked with each other. Pyrite minerals are also found in the rock as opaque.

The X-ray diffractometers taken in the soil body to determine the mineralogical properties of the PI and PII numbered profiles opened in the study area are given in Figure 5. Smectite, muscovite, and quartz minerals were determined from the primary minerals in the body of the soil profile numbered PI (Table 3). Quartz, muscovite, and smectite minerals were determined in order of density. While the amount of quartz does not change with the depth, the muscovite mineral's intensity has increased, but the dominant mineral has been quartz. It is a conglomerate containing quartz and radiolarite fragments in a sand matrix in mineralogical and petrographic thinning. Most of the pebbles that make up the rock are quartz grains, and the other grains are made up of pebbles of rocks such as chert, quartzite, and schist. These grains are bound together by a matrix of silt, clay, and sand size. The smectite mineral in the environment indicates the presence of feldspar. Mineralogical and petrographic studies reveal that the rock contains very dense fractures, cracks, and sometimes melting cavities, and these are filled with spar calcites.

Primary minerals in the body of the soil profile numbered PII were identified as smectite, muscovite, quartz, cristobalite, and calcite (Table 3). In order of density, quartz muscovite, calcite, cristobalite, smectite were determined. No change in the mineralogical order was observed with the depth in the profile. It is a litharenite composed of quartz, sparse plagioclase, mica, and rock fragments interconnected with carbonate cement in mineralogical and petrographic thinning. The rock fragments that make up the main percentage of the rock are composed of fragments of rocks such as limestone, mudstone, siltstone, shale, chert, 
sandstone, quartzite, and schist. Cristobalite $\left(\mathrm{SiO}_{2}\right)$ is a polymorph of silica minerals formed at high temperatures by transforming from diatom fossil deposits or acidic volcanic rocks. At high temperatures, quartz directly turns into a cristobalite mineral (Ataser, 2010). However, it is thought that the profile with a high slope, whose intensity has decreased with the mineral depth seen, may have come with superficial transport.

The X-ray diffractometers taken in the soil body to determine the mineralogical properties of the PIII and PIV numbered profiles opened in the study area are given in Figure 6. PIII soil profile is formed on limestone parent material with Ap-AC-Cr horizon sequence. Among the primary minerals, muscovite, smectite, sanidine, quartz, and calcite were found in the soil body. The Cr horizon did not include muscovite, smectite, sanidine, and quartz minerals (Table 3). As the soil profile formed on the limestone main material in the colluvial deposit position reached the Cr horizon, the parent material's activity increased. Secondary peaks of muscovite, sanidine and quartz minerals were not observed. The intensity of the calcite peaks increased in parallel with the limestone, increasing the material efficiency. Calcite, quartz, muscovite, sanidine, and smectite were determined in order of density (Table 3).

The PIV soil profile has formed on the limestone-colluvial deposit parent material in the Ap-Ad2-Bss-C horizon sequence. Smectite, muscovite, microcline, orthoclase and quartz were found in the soil body. Furthermore, the secondary peaks of microcline, orthoclase, and muscovite minerals were determined only in the Ap horizon, while the muscovite mineral peaks were determined in the Ap and Ad2 horizon. In order of density, quartz, microcline, orthoclase, muscovite, smectite were determined. The abundance of microcline and orthoclase minerals decreased with depth, and muscovite became the second mineral during abundance (Table 3). The profile with colluvial character and stony terrain is very high from the host rocks (Beckmann and Thisse. 1987). 
The clay fraction X-ray diffractometers are given in Figure 7 to determine the mineralogical properties of the soil profiles of the study area. In the profiles saturated with $\operatorname{Mg}(\mathrm{Mgad})$, the peak crystallized between $14.81-17.67 \AA$. The secondary peak at $8.24 \AA$ was opened to 17.44-21.32 $\AA$ in the application of MgEG (Mg Ethylene Glycol). Peaks indicate the presence of poorly crystallized smectite minerals. The peaks seen in the range of 9.71$10.15 \AA$ in all applications belong to well-crystallized illite. The peaks seen in the range of 7.03-7.23 $\AA$ for the samples saturated with Mgad, MgEG, and Kad disappeared when heated at $550^{\circ} \mathrm{C}\left(\mathrm{K} 550^{\circ} \mathrm{C}\right)$. It indicates that these peaks belong to crystallized kaolinite. In all applications, peaks seen in the range of 12.16-15.60 $\AA$ and 11.35-12.10 $\mathrm{A}$, respectively, belong to weakly crystallized chlorite and clay minerals with illite-chlorite interlayers. In the order of abundance, the distribution of clay in the surface horizon is illite, kaolinite and smectite, chlorite and illite-chlorite interlayered clay minerals, while in $\mathrm{Bw}$ and $\mathrm{C}$ horizons, it is in the form of clay minerals with illite, smectite, kaolinite, chlorite and illite-chlorite interlayers.

The weakly crystallized peaks in the range of $12.98-13.18 \AA$ in the samples saturated with $\mathrm{Mg}(\mathrm{Mgad})$ in the soils numbered PII was opened to $17.94-18.09 \AA$ in the application of MgEG (Mg Ethylene Glycol). Peaks indicate the presence of poorly crystallized smectite minerals. The peaks in the range of 9.75-10.08 $\AA$ in all applications belong to the crystallized illite. The peaks seen in the range of 6.99-7.18 $\AA$ for samples saturated with Mgad, MgEG, and $\mathrm{Kad}$ disappeared when heated at $550^{\circ} \mathrm{C}\left(\mathrm{K} 550^{\circ} \mathrm{C}\right)$. It indicates that these peaks belong to crystallized kaolinite. The peaks in the range of 13.62-14.71 $\AA$ in all applications belong to weakly crystallized chlorite. In the order of abundance, the distribution of clay in the surface horizon is as illite, kaolinite, smectite, and chlorite. In contrast, chlorite and smectite minerals are replaced with depth (Table 4). An increase in the peak intensity of the crystallized chlorite and smectite minerals with depth was detected. 
The weakly crystallized peaks in the range of 14.66-15.12 $\AA$ in the samples saturated with $\mathrm{Mg}(\mathrm{Mgad})$ in the soil profile of the study area PIII were opened to the range of 19.02-20.06 $\AA$ in the application of MgEG (Mg Ethylene Glycol). Peaks indicate the presence of poorly crystallized smectite minerals. The peaks in the range of 9.77-10.13 $\AA$ in all applications belong to the crystallized illite. The peaks seen in the range of 7.03-7.22 $\AA$ for the samples saturated with Mgad, MgEG, and potassium saturation (Kad) disappeared when heated at $550^{\circ} \mathrm{C}\left(\mathrm{K} 550^{\circ} \mathrm{C}\right)$. It indicates that these peaks belong to crystallized kaolinite. The peaks seen in the range of $13.30-14.76 \AA$ in all applications belong to uncrystallized chlorite. Also, peaks seen between 6.43-6.61 $\AA$ in Ap and AC horizons in all applications belong to feldspar mineral in clay size. In the order of abundance, the distribution of clay in the surface horizon is as illite, kaolinite, smectite, and chlorite, chlorite, and smectite minerals replaced with depth. A decrease in the peak intensities of the minerals was determined with the depth (Table 4). The reduction in peak intensity is associated with the increase for sand (46.27\%) and the texture of the sandy loam.

The well-crystallized peaks at 15.54 and $15.99 \AA$ in the samples saturated with $\mathrm{Mg}$ (Mgad) in the soil profile numbered PIV were opened to the range of 17.87-18.54 $\AA$ in the application of MgEG (Mg Ethylene Glycol). In potassium saturation (Kad), these peaks are closed to the range of 12.91-13.26 А. Peaks indicate the presence of well-crystallized smectite minerals. The peaks seen in the range of 9.69-10.11 $\AA$ in all applications belong to crystallized illite. The peaks seen in the range of 7.04-7.26 $\AA$ for samples saturated with Mgad, MgEG, and Kad disappeared when heated at $550^{\circ} \mathrm{C}\left(\mathrm{K} 550^{\circ} \mathrm{C}\right)$. It indicates that these peaks belong to weakly crystalline kaolinite. In the order of abundance, the distribution of clay is in the form of smectite, illite, and kaolinite (Table 4). A decrease in the illite peak intensity was observed in the Ad2 horizon, but there was no change in the order. 
When the distribution of clay minerals in the profiles was examined, the smectite mineral determined at the PI, PII, and PIII profiles at a deficient and medium level was determined as more very abundant in the PIV profile. All profiles contain illite and kaolinite minerals. The PIV profile did not determine the chlorite mineral in low and medium levels in PI, PII, and PIII profiles. The high amount of swelling clay, having cracks extending deep from the surface in dry seasons and causing sliding surfaces to be seen in the profile from place to place, increases the transport with the slope.

Material losses due to moving and erosion in slope lands and accumulations in near or bottom lands are expected. The presence of smectite clay minerals in these profiles is the result of the change in physiographic units. In the colluvial PIV, accumulations in smectite clay minerals have been determined with the transport. In the study conducted by Tuncay et al. (2020), smectite was determined as the dominant mineral in soils formed in footslope and bottomland physiographic units. Further, another study by Yaneva et al. (2015) stated that kaolinite clay minerals dominate the bottom lands where the slope is reduced.

\section{Weathering indices and mass balance of soils}

The values of the weathering indices of the profile horizons belonging to the study area are given in Table 5. The difference in weathering index values obtained in each profile horizon was statistically significant $(\mathrm{p}<0.01)$. Generally, the changes of weathering indices in profiles were similar. According to the CIA, CIW, and PIA values, PI and PIV were similar, showing PII> PIII.

There are significant variations in the indices of dissociation resulting from the physiographic difference. It was determined that soil formation processes were more effective in PIV profile with in situ summit and footslope slope. Thus, the weathering indices were higher than the others. According to the CIA classification values stated by Nesbitt and 
Young (1982), the soil profiles PII and PIII were determined as "undissociated" $(\leq 50)$, and the soil profiles PI and PIV numbered as slightly decomposed (60-80\%). The CIA value can reach $100 \%$ in soil, and sedimentary material where leaaching and decomposition are intense and kaolinite and gibbsite clay minerals are present (Ozaytekin et al., 2012). In shale rocks, it varies between 70-75\% (Tuncay et al., 2019). It is evident that in PII and PIII profiles, there are differences in water penetration into the soil and washing depending on the physiographic unit. The classification belonging to the CIA is valid within the CIW. Harnois (1988) proposed the CIW classification in a modified approach by removing $\mathrm{K}_{2} \mathrm{O}$ from the CIA. $\mathrm{Al}$ is immobile compared to $\mathrm{Ca}$ and $\mathrm{Na}$ elements, and increases in the decomposition degree with high mobility of $\mathrm{Na}$ and $\mathrm{Ca}$ increase CIW. Soil profiles PII and PIII are "undissociated" (50) and generally have high levels of decomposition (80-100\%) in PI and PIV profiles. The CIW used in evaluating profile leaching was determined as $90.35 \%$ at the highest level of the PI profile's leach zone $(\mathrm{Bw})$. The PIA index used to reveal the degree of alteration of plagioclases showed similar changes with other indices of decomposition.

In the CIA, CIW profiles, and PIA indices increasing with depth, mostly $\mathrm{MgO}, \mathrm{CaO}$, $\mathrm{Na}_{2} \mathrm{O}$, and $\mathrm{K}_{2} \mathrm{O}$ elements tend to increase with movement depending on the depth (Alsalam, 2020). Additionally, high results in $\mathrm{Ca}$ and $\mathrm{Mg}$ values indicate the presence of plagioclase in the environment, which did not decompose. The other factor in PIA values' high results is plagioclase in the environment where the decomposition levels are at the initial stage of excessive fragmentation. As a result of the clay action, $\mathrm{Al}_{2} \mathrm{O}_{3}$ values decrease. It is also used as an indicator of fragmentation and decomposition. The base $/ \mathrm{R}_{2} \mathrm{O}_{3}$ index is determined as the major basic cation concentration $(\mathrm{Mg}, \mathrm{Ca}, \mathrm{Na}$ and $\mathrm{K})$ ratio to relatively inert elements $(\mathrm{Al}, \mathrm{Fe}$, and $\mathrm{Ti}$ ). The base $/ \mathrm{R}_{2} \mathrm{O}_{3}$ ratio, which generally gives results between $1-10$, is below 1 , which indicates the mobility of basic cations in the profile. Therefore, it is seen that basic cations are 
leached out, and decomposition occurs in PI and PIV profiles. Bases $/ \mathrm{R}_{2} \mathrm{O}_{3}$ ratio decreases as the weathering increases in soils (Mourier, 2008).

The mass balance model is used to quantify the amount resulting from loss/gain and transformations for any element during the soil formation period (Brimhall and Dietrich, 1987). The horizon's bulk density and chemical contents and the parent material or bedrock must be known to reveal the mass balance model (Brimhall et al.,1991). The mass balance equation has been developed to reveal open system losses/gains concerning the decomposition of soils and the parent material based on these features. Brimhall and Dietrich (1987), Brimhall et al. (1991), and Chadwick et al. (1990) tried to reveal the volumetric and mass changes of soils during their formation.

Stationary elements such as $\mathrm{Ti}$ or $\mathrm{Zr}$ are used to produce such loss/gain values. Ti element was used in the study (Brimhall and Dietrich, 1987; Harden, 1988, Chadwick et al., 1990; Brimhall et al, 1991). Langley-Turnbaugh and Bockheim (1998); successfully applied it on rocks rich in silicates. Egli and Fitze (2000) have revised the method. There are also sedimentary rocks in the study area. It was also applied to the soils formed on this main material to test the method's success. If $\mathrm{M}_{\text {jflux }}$ is negative, it indicates loss from the system; if it is positive, it indicates participation in the system.

About $70-80 \%$ of quartz, plagioclase and K-feldspar minerals dominate the earth's crust (Nesbitt and Markovics, 1997). The movement and loss of alkali and alkaline earth elements are good indicators of the disintegration-decomposition state (Nesbitt et al., 1980). Alkali and alkaline earth elements ( $\mathrm{Na}, \mathrm{K}, \mathrm{Ca}$, and $\mathrm{Mg}$ ) move away in arid-semi-arid climatic conditions. The mass balance indexes and changes in loss gains of the study area's soil profiles are given in Table 6.

The mass function gave negative results for all cations (except PIV) except for the PI profile, $\mathrm{K}$ and PII profile $\mathrm{Na}$. The greatest loss was determined as $\mathrm{Ca}\left(-583.74 \mathrm{~g} \mathrm{~cm}^{-2}\right)$ in the 
PIII profile at the back slope. Mass transport values give negative results in profiles with pedological development. The profile in the foot slope position, on the other hand, showed positive results in terms of cations due to its accumulation position. Although silicon gains movement in tropical climates, it is open to transportation, especially in sloping lands. While negative mass transport results were obtained in PII and PIII numbered profiles in A-AC horizon sequence (weak profile development), PI and PIV numbered physiographic units were gained in summit and footslope units, respectively. Since the PI profile is limestone with silicon interlayer, it gives high $\mathrm{SiO}_{2}$ values, which increased the summit physiographic unit's gain. Aluminum is enriched in advanced soil formation processes (Hill et al., 2000; Kurtz et al., 2000). Al, a mobile element, gave negative results in calculations. Soil formation processes are expected to give negative results in profiles in the initial stage (Gardner 1980; Gardner 1992; Jin et al. 2010; Taboada et al. 2006). Although limestone is the main material, the studied profiles, due to the superficial transport, from the parent materials of the surrounding magmatic origin and especially the biotite mineral origin, gave net negative results except for the PIII profile. While the PIV profile showed negative results for $\mathrm{Al}$ and $\mathrm{Fe}$ in Ap and Ad horizons, it gave a positive anomaly value due to the accumulation of clay and sesquioxide in the Bss horizon, albeit a little (Oh and Richter, 2005).

\section{Relationships between the physical and mineralogical characteristics of soils}

Some of the physical properties of the profiles are specified in Table 7. The aggregate stability in profiles varied between $51.74-63.74 \%$, and the change between horizons was not statistically significant $(\mathrm{P}<0.01)$.

As determined at the lowest level in PII profile was determined at high levels in soils, showing the backslope physiographic unit (PIII) with high lime content. In summit physiography, it is thought that the reason for these values is that there is not much erosion 
and transport in situ and the clay content, which is effective in aggregation, is high. In aggregates in the soil, clay minerals, organic origin colloidal substances, iron, aluminum, manganese oxides, and calcium carbonate are among the influential parameters. (Branick and Lal, 2005). Lime and gypsum added to the soil provide more stable aggregates (Chan and Heenan, 1999).

While the change between FC (19.32-48.50\%) and WP (11.02-35.40\%) values in profile horizons is statistically significant, this change in AWC (8.30-13.90\%) was determined to be insignificant. Field capacity and wilting point are determined at the lowest PII. These horizons have low clay content, and clay minerals are generally minerals with low swelling shrinkage potential. Due to these features, water retention is determined to be low. Smectite is a clay type with a 2: 1 lattice structure, swelling shrinkage, and high water retention (Laird, 2016). Field capacity and wilting point were determined in the highest foot slope physiographic unit. In this profile, the clay amount is high, and the abundance level of smectite minerals is high. Available water content was determined in the highest backslope physiographic unit. The low density of the smectite clay mineral in the PIII profile is thought to cause the water content held at the wilting point to be lower, depending on the amount of clay. The available water content increases when water's retention energy decreases with decreased wilting point values. Although field capacity varies significantly depending on texture, organic matter, and structure (Karahan et al., 2014), the variety and amount of clay minerals effectively change the wilting point. (Lal and Shukla, 2004). Again, the high lime content in the PIII profile and the porosity above the average caused the field capacity to be determined at high levels after PIV.

The bulk density values of the profiles $\left(1.37-1.53 \mathrm{~g} \mathrm{~cm}^{-3}\right)$ varied insignificantly, and the porosity (34.91-48.67\%) varied at a statistically significant level. PIII and PIV profiles' Ap horizon is the release horizon and has a lower bulk density and higher porosity than other 
horizons. With the processing, the bulk density decreases as the aeration pores increase on the soil surface and the penetration resistance decreases (Kuhwald et al., 2020). At the depths of the subsoil, the bulk density increase over time and the porosity decreases. The presence of an Ad horizon in the PIV profile indicates a horizon with a root boundary, and an increase in bulk density values has been observed in this horizon. In general, increases in bulk density were determined with the increase for clay.

The relationships showing the correlations of soil physical properties with clay mineral density and physiographic unit are shown in Table 8.

The physiographic unit (from the summit to footslope) and smectite showed a positive correlation with clay mineral $(\mathrm{p}<0.05 ; 0.363)$ and a negative correlation with kaolinite and illite. As a result of determining the increases in the soils' field capacity from the summit to the bottom land unit's, significant positive relationships were found. Yilmaz et al.(2005). determined positive relationships with the structure stability index and smectite clay type and negative kaolinite clay mineral. In the study, while the smectite clay mineral increased, the aggregate stability increased due to the increased amount of clay, organic material, and lime content. A negative relationship was determined between kaolinite and illite, and smectite. No significant relationship could be determined between aggregation and clay minerals. A statistically negative relationship was determined between field capacity and wilting point and kaolinite clay mineral. Positive $(0.506 ; \mathrm{p}<0.01)$ negative relationships between kaolinite and illite were found between available water and physiographic unit. The study determined that lime content and clay mineral type are effective on physical properties, except the effect of organic material. Yilmaz and Alagoz (2005) stated that the effect of humic substances on aggregation is low in soils with Montmorollionite clay content and high lime values.

\section{CONCLUSION}


This study investigated the relationships between clay mineralogy and weathering indices and physicochemical properties of soils formed on sedimentary rocks with different physiographic units. Soil profiles in different physiographic units are soils formed on limestone parent material classified in Entisol Inseptison and Vertisol ordo. In the soils whose common primary minerals are calcite and quartz, kaolinite and illite minerals in the summit's physiographic unit and the smectite clay minerals in the foot slope unit are densely determined. While negative mass transport results were obtained in PII and PIII numbered profiles, which showed weak development, PI and PIV numbers were gained in summit and foot slope physiographic units, respectively. Similarly, weathering indices values were determined at high levels in the summit and footslope physiographic units and lower levels in other units. In soils' physical properties, aggregate stability was determined in PI and PIV profiles at a high level. Field capacity and wilting point values increased with the presence of smectite clay minerals. Bulk density values varied depending on the land use type and differences in the horizons but did not significantly vary depending on the physiographic units.

As a result of this study, the differences in the clay minerals of the soils formed on the limestone main material under the same climatic conditions and the variations in the soil formation processes according to physiographic units were revealed. It has been determined that soil formation processes occur faster in the in situ summits and footslope physiographic unit. Statistically significant variations in physical properties were found within the soil profile due to weathering. It has been revealed that due to the accumulation of smectite clay minerals in the soil formed on the bottom lands, the water retention properties of the soils are high, and the segregation is more advanced than the other units.

\section{DECLARATION OF INTEREST STATEMENT}


The authors declare that they have no known competing financial interests or personal relationships that could have appeared to influence the work reported in this paper.

\section{ACKNOWLEDGEMENTS}

This study was supported financially by The Scientific and Technological Research Council of Turkey (TÜBİTAK-118O282). The authors gratefully acknowledge the scientific research grant from the Scientific and Technological Research Council of Turkey.

\section{REFERENCES}

Aboudi Mana, S.C., Hanafiah, M.M., Chowdhury, A.J.K., 2017. Environmental characteristics of clay and clay-based minerals. Geology, Ecology, and landscapes, 1(3), 155-161.

Aiuppa, A., Allard, P., D’Alessandro, W., Michel, A., Papello, F., Treuil, M., Valenza, M., 2000. Mobility and Fluxes of Major, Minor and Trace Metals During Basalt Weathering and Groundwater Transport at Mt. Etna Volcano (Sicily). Geochim. Cosmochim. Acta, 64, 1827-1841 https://doi.org/10.1016/s0016-7037(00)00345-8

Anonymous, 1973. Analytical Methods for A.A. Spektrometry. Perkin Elmer. Norwalk, Connecticut, USA.

Ataşer, H.O., 2010. An Investigation of Sintering and Mechanical Properties of Amorphous Silica with Andalusite as an Additive. Istanbul University, Institute of Science, Master's Thesis, p 55 (unpublished).

Beckmann, M. J., Thisse, J. F., 1987. The location of production activities. In Handbook of regional and urban economics (Vol. 1, pp. 21-95). Elsevier.Birkeland PW. 1999. Soils and Geomorphology. 3rd ed. New York:Oxford University Press.

Brimhall, G. H., Dietrich, W. E., 1987. Constitutive mass balance relations between chemical composition, volume, density, porosity, and strain in metasomatic hydrochemical systems: results on weathering and pedogenesis. Geochimica et Cosmochimica Acta, 51(3), 567-587. https://doi.org/10.1016/0016-7037(87)90070-6

Brimhall, G. H., Ford, C., Bratt, J., Taylor, G., Warin, O., 1991. Quantitative geochemical approach to pedogenesis: importance of parent material reduction, volumetric expansion, and eolian influx in lateritization. Geoderma, 51(1-4), 51-91. https://doi.org/10.1016/0016-7061(91)90066-3

Bronick C.J., Lal, R., 2005. Soil Structure and Management: a Review, Geoderma, 124, 3-22. https://doi.org/10.1016/j.geoderma.2004.03.005 
Chadwick, O. A., Brimhall, G.H. and Hendricks, D.M., 1990. From a black to a gray box-a mass balance interpretation of pedogenesis. Geomorphology, 3 (3-4), 369-390.

Chan, K.Y., Heenan, D. P., So, H. B., 2003. Sequestration of Carbon and Changes in Soil Quality under Conservation Tillage on Lighttextured Soils in Australia: a review, Australian Journal of Experimental Agriculture, 43, 325 - 334. https://doi.org/10.1071/ea02077

Chesworth, W., Dejou, J., Larroque, P., 1981. The Weathering of Basalt and Relative

Mobilities of the Major Elements at Belbex, France. Geochim. Cosmochim. Acta, 45, 1235-1243. https://doi.org/10.1016/0016-7037(81)90147-2

Dengiz, O., Başkan, O., 2010. Characterization of soil profile development on different landscape in semi-arid Region of Turkey a case study; Ankara-Soğulca catchment. Journal of Anadolu Agricultural Science, 25 (2): 106-112.

Dengiz, O., Şenol, H., 2018. Effect of toposequences on geochemical mass balance and clay mineral formation in soils developed on basalt parent material under subhumid climate condition. Indian Journal of Geo Marine Science, 47(9): 1809-1820.

Dengiz, O. Sağlam, M., Özaytekin, H.H., Baskan, O., 2013. Weathering Rates and Some Physico-Chemical Characteristics of Soils Developed on A Calcic Toposequences. Carpathian Journal of Earth and Environmental Sciences 8 (2), 13 - 24.

Egli, M., Fitze, P., 2000. Formulation of pedologic mass balance based on immobile elements: a revision, Soil Science, 165 (5), 437-443. https://doi.org/10.1097/00010694200005000-00008

Egli, M., Mirabella, A., Fitze, P., 2001. Clay Mineral Formation in Soils of Two Different Chronosequences in The Swiss Alps. Geoderma, 104; 145-175.

Egli, M., Mirabella, A., Sartori, G. and Fitze, P., 2003. Weathering rates as a function of climate: results from a climosequence of the Val Genova (Trentino, Italian Alps). Geoderma, 111 (1-2), 99-121.

Fedo, C.M., Nesbitt, H.W., Young, G.M., 1995. Unraveling the effects of potassium metasomatism in sedimentary rocks and paleosols, with implications for paleoweathering conditions and provenance. Geology 23, 921-924. https://doi.org/10.1130/0091-7613(1995)023<0921:uteopm>2.3.co;2

Fernández-Ugalde, O., Barré, P., Hubert, F., Virto, I., Girardin, C., Ferrage, E., ... Chenu, C. 2012. To what extent clay mineralogy affect soil aggregation? Insights from 
fractionation analyses conducted on soils under different land-uses. In EGU General Assembly Conference Abstracts (p. 6427).

Fissore, C., Jurgensen, M. F., Pickens, J., Miller, C., Page-Dumroese, D., Giardina, C. P., 2016. https://doi.org/10.1002/ecs2.1605. Ecosphere, 7(11), e01605.

Gardner, L.R., 1980. Mobilization of $\mathrm{Al}$ and $\mathrm{Ti}$ during weathering- Isovolumetric geochemical evidence. Chemical Geology 30(1- 2): 151-165. https://doi.org/10.1016/0009-2541(80)90122-9

Gardner, L.R., 1992. Long-term isovolumetric of aluminum from rocks during weathering: Implications for the genesis of saprolite. Catena 19: 521-537. https://doi.org/10.1016/0341-8162(92)90051-c

Harden, J. W., 1988. Genetic interpretations of elemental and chemical differences in a soil chronosequence, California. Geoderma, 43(2-3), 179-193. https://doi.org/10.1016/0016-7061(88)90042-0

Harnois, L., 1988. The CIW index: a new Chemical Index of Weathering. Sedimentary Geology 55, 319- 322.

Hill, I.G., Worden, R.H., Meighan, I.G., 2000.) Yttrium: The immobility-mobility transition during basaltic weathering. Geology 28(10): 923-926. https://doi.org/10.1130/00917613(2000)028<0923:ytimtd > 2.3.co;2

Jin, L., Ravella, R., Ketchum, B., Bierman, P.R., Heaney, P., White, T., Brantley, S.L., 2010. Mineral weathering and elemental transport during hillslope evolution at the Susquehanna/Shale Hills Critical Zone Observatory. Geochimica et Cosmochimica Acta 74: 3669-3691.

Joffe, J. S., 1949. Pedology (Vol. 68, No. 4, p. 346). LWW.

Jones, C.A., 1983. Effect of soil texture on critical bulk densities for root growth. Soil Sei. Soc. Amer. J. 42:565-570

Karahan, G., Erşahin, S., Öztürk, H.S., 2014. Field Capacity Dynamics Affected by Soil Properties. Journal of Agricultural Faculty of Gaziosmanpasa University. 30 (1), 1-9.

Kemper, W.D., Rosenau, R.C., 1986. Aggregate stability and size distribution. In: Klute, A. (Ed.), Methods of Soil Analysis: Part I, 2nd ed. ASA, Madison, Wisconsin, pp. 425442 .

Klute, A., 1986. Water retention. Laboratory methods. In Klute, A. (ed). Methods of soil analysis. Part 1. Phsical and mineralogical methods. 2nd ed. Agronomy 9: 635-662 
Kuhwald, M., Hamer, W. B., Brunotte, J., Duttmann, R., 2020. Soil Penetration Resistance after One-Time Inversion Tillage: A Spatio-Temporal Analysis at the Field Scale. Land, 9(12), 482.

Kurtz, A.C., Derry, L.A., Chadwick, O.A., Alfano, M.J. 2000. Refractory element mobility in volcanic soils. Geology 28(8): 683-686.

Laird, D.A., 2006. Influence of layer charge on swelling of smectites. Applied clay science, 34(1-4), 74-87.

Lal, R., Shukla, M. K., 2004. Principles of Soil Physics. New York: CRC Press.

Langley-Turnbaugh, S., Bockheim, J., 1998. Mass balance of soil evolution on late Quaternary marine terraces in coastal Oregon, Geoderma, 84 (4), 265-288.

Lybrand, R. A., Rasmussen, C., 2018. Climate, topography, and dust influences on the mineral and geochemical evaluation of granitic soils in southern Arizona, Geoderma 314: $245-261$

Mandel, R.D. Bettis, E.A., 2001. Use and Analysis of Soil by Archaeologists and Geoscientists. In Earth Sciences and Archaeology. (P. Goldberg, V.T. Holliday, C.R. Ferring, eds.), New York, Plenum Press, pp. 173-204.

Mavris, C., Egli, M., Plötze, M., Blum, D.J., Mirabella, A., Giaccai, D., Haeberli, W., 2010. Initial Stages of Weathering and Soil Formation in The Morteratsch Proglacial Area (Upper Engadine, Switzerland). Geoderma, 155, 359-371.

Morgan, R.P.C., 2005. Soil erosion and conservation. 3rd Edition, Blackwell publishing, Oxford, UK, 303 pp.

Mourier, B., Poulenard, J., Chauvel, C., Faivre, P., Carcaillet, C.2008. Distinguishing subalpine soil types using extractible $\mathrm{Al}$ and $\mathrm{Fe}$ fractions and REE geochemistry. Geoderma, 145, 107-120, https://doi.org/10.1016/j.geoderma.2008.03.001, 2008.

MTA, 2011. 1 / 100,000 scale Geological Map of Turkey, 158-162 sheets.Ankara.

Narloch, P., Woyciechowski, P., Kotowski, J., Gawriuczenkow, I., Wójcik, E., 2020. The Effect of Soil Mineral Composition on the Compressive Strength of Cement Stabilized Rammed Earth. Materials, 13(2), 324. https://doi.org/10.3390/ma13020324.

Nesbitt, H.W., Markovics, G., 1997. Weathering of granodioritic crust, long term storage of elements in weathering profils, and petrogenesis of siliciclastic sediments. Geochimica et Cosmochimica Acta 61: 1653-1670. https://doi.org/10.1016/S0016-7037(97)000318 
Nesbitt, H.W., Markovics, G., Price, R.C., 1980. Chemical processes affecting alkalis and alkaline earths during continental weathering. Geochimica et Cosmochimica Acta 44(11): 1659- 1666. https://doi.org/10.1016/0016-7037(80)90218-5

Nesbitt, H. W., Wilson, R. E., 1992. Recent Chemical Weathering of Basalt. American Journal of Science, 292, 740-777. https://doi.org/10.2475/ajs.292.10.740

Nesbitt, H.W., Young, G.M., 1982. Early Proterozoic climates and plate motions inferred from major element chemistry of lutites. Nature 299, $715-717$

Oh, N.H., Richter, D.D., 2005.Elemental translocation and loss from three highly weathered soil-bedrock profiles in the southeastern United States. Geoderma 126(1-2): 5-25. https://doi.org/10.1016/j.geoderma.2004.11.005

Özaytekin, H.H., Mutlu, H.H., Dedeoglu, M., 2012. Soil formation on a calcic chronosequence of Ancient Lake Konya in Central Anatolia, Turkey. Journal of African Earth Sciences, 76, 66-74. https://doi.org/10.1016/j.jafrearsci.2012.09.002

Özaytekin, H.H., Dedeoğlu, M, 2021. Weathering rates and mass balance of soils developed on hasandağ volcanic materials. Anadolu Journal of Agricultural Sciences, 36; 81-92 https://doi.org/10.7161/omuanajas.789497

Phillips, R. D., Rojstaczer, S., 2001. Chemical Weathering in a Region of Active Orogeny: Pescadero Creek Watershed, California. Glob. Biogeochem. Cycles, 15, 383-391 https://doi.org/10.1029/1999GB001187

Pires, A.C.D., Melo, V.F., Lima, V.C., Motta, A.C.V., 2007. Major Soil Classes of The Metropolitan Region of Curitiba (PR), Brazil: I-Mineralogical Characterization of The Sand, Silt and Clay Fractions. Brazilian Archives of Biology and Technology. Vol: 50 No:2. Curitiba. http://dx.doi.org/10.1590/S1516-89132007000200001

Richards, L. A., 1954. Diagnosis and Improvement Saline and Alkaline Soils. U.S. Dep. Agr. Handbook 60.

Saricaoğlu, S., Dengiz, O., Işik, K., 2020. Assessment of Biogeochemical-Mineralogical Characteristic and Weathering Indices of Soils Developed on Basaltic Parent Material and Toposequence Under Subhumid Ecosystem. Geomicrobiology Journal, https://doi.org/10.1080/01490451.2021.1879971

Schaetzl, R., Anderson, S., 2005. Soil Genesis and Geomorphology, ISBN-10 0-521-81201-1.

Simonson, R. W., 1959. Outline of a generalized theory of soil genesis. Soil Sci. Soc. Am.

Proc .23: 152 -156. https://doi.org/10.2136/sssaj1959.03615995002300020021x

Singer, A., 1994. Clay mineralogy as affecting dispersivity and crust formation in Aridisols. In 'Transactions of 15 th world congress of soil science. Acapulco, Mexico' (Ed. 
J.D.Etchevers.), 8a: 37-46. (International Society of Soil Science, Mexican Society of Soil Science: Mexico.).

Soil Survey Staff, ,1993. Soil Survey Staff. Soil Survey Manual. USDA, Handbook No: 18, Washington D.C., P: 437.

Soil Survey Staff,, 1999. Soil Survey Staff. Soil Taxonomy. A Basic System of Soil Classification for Making and Interpreting Soil Survey. USDA, Agriculture Handbook, No: 436 Washington, D.C.

Soil Taxonomy., 2014. Keys to Soil Taxonomy. United States. United States Department of Agriculture Natural Resources Conservation Service, p. 372

Sommer, M., Gerke, H.H., Deumlich, D., 2008. Modelling soil landscape genesis-A "time split” approach for hummocky agricultural landscapes. Geoderma 145 (2008) 480493. https://doi.org/10.1016/j.geoderma.2008.01.012

Taboada, T., Cortizas, A.M., García, C., García-Rodeja, E., 2006. Particle-size fractionation of titanium and zirconium during weathering and pedogenesis of granitic rocks in NW Spain. Geoderma 131: 218-236. https://doi.org/10.1016/j.geoderma.2005.03.025

Tuğyan, G., Sungur, A., 2020. Determination of Heavy Metal Concentrations in Soil Formed on Different Parent Materials (Kırklareli, Turkey). ÇOMÜ LJAR, 1 (1), 40-47.

Tunçay T, Dengiz O,, Bayramin İ, Kılıç, Ş. Başkan, O. 2019. Chemical weathering indices applied to soils developed on old lake sediments in a semi-arid region of Turkey. Eurasian Journal of Soil Science 8(1): 60-72. https://doi.org/10.18393/ejss.499122

Tunçay, T., Dengiz, O. 2020. The roles of parent material and toposequence on geochemical characteristics and pedogenic iron oxides of soils. Indian Journal of Geo Marine Science, 49(4): 622-623.

Tunçay, T., Dengiz, O., İmamoğlu, A., 2020. Influence of toposequence on physical and mineralogical properties of soils developed on basaltic parent material under subhumid terrestrial ecosystem. Journal of Agricultural Sciences, 26(1), 104-116. https://doi.org/10.15832/ankutbd.499353

White, A. F., 1983. Surface Chemistry and Dissolution Kinetic of Glassy Rocks at $25^{\circ} \mathrm{C}$.

Geochim. Cosmochim. Acta, 47, 805-816. https://doi.org/10.1016/0016-7037(83)90114-X

White, R. E., 2013. Principles and practice of soil science: the soil as a natural resource. John Wiley \& Sons.

WRB., 2014. World reference base for soil resources. International soil classification system for naming soils and creating legends for soil maps. Food and Agriculture Organization of United Nations, World Soil Resources Reports; 6, p.203 
Yaneva, M., Stanimirova, T., Kenderova, R., 2015. Comparative mineralogical characteristics of red soils from South Bulgaria. Eurasian Journal of Soil Science, 4(2), 100-106.

Yılmaz, E., Alagöz, Z., 2005. Aggregate Formation and Stability in Soil. 19 (36), 78-86

Yılmaz, K., Çelik, I., Kapur, S., Ryan, J., 2005. Clay minerals, Ca/Mg ratio and Fe-Al-oxides in relation to structural stability, hydraulic conductivity and soil erosion in southeastern Turkey. Turkish journal of agriculture and forestry, 29(1), 29-37.

Young, R., 2012.Soil properties and behaviour. Vol. 5. Elsevier, 


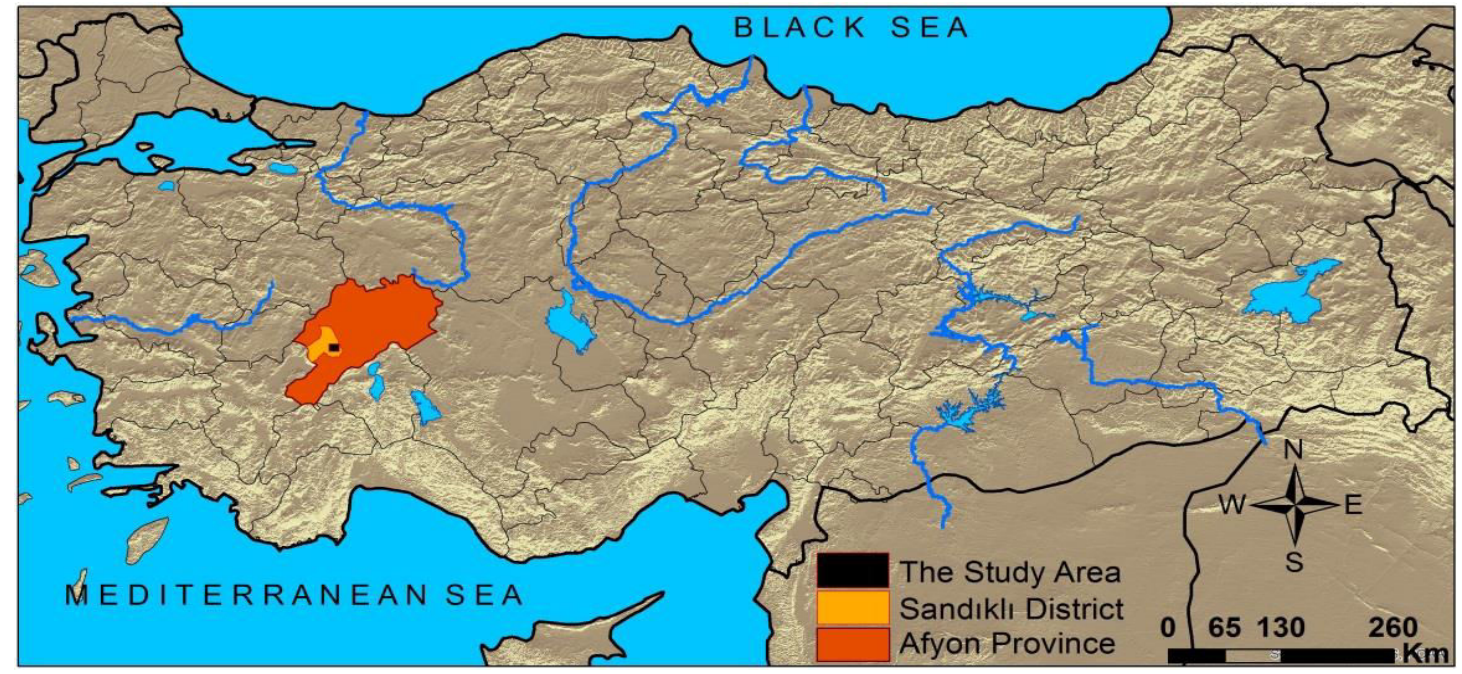

Figure 1. Location of the study area

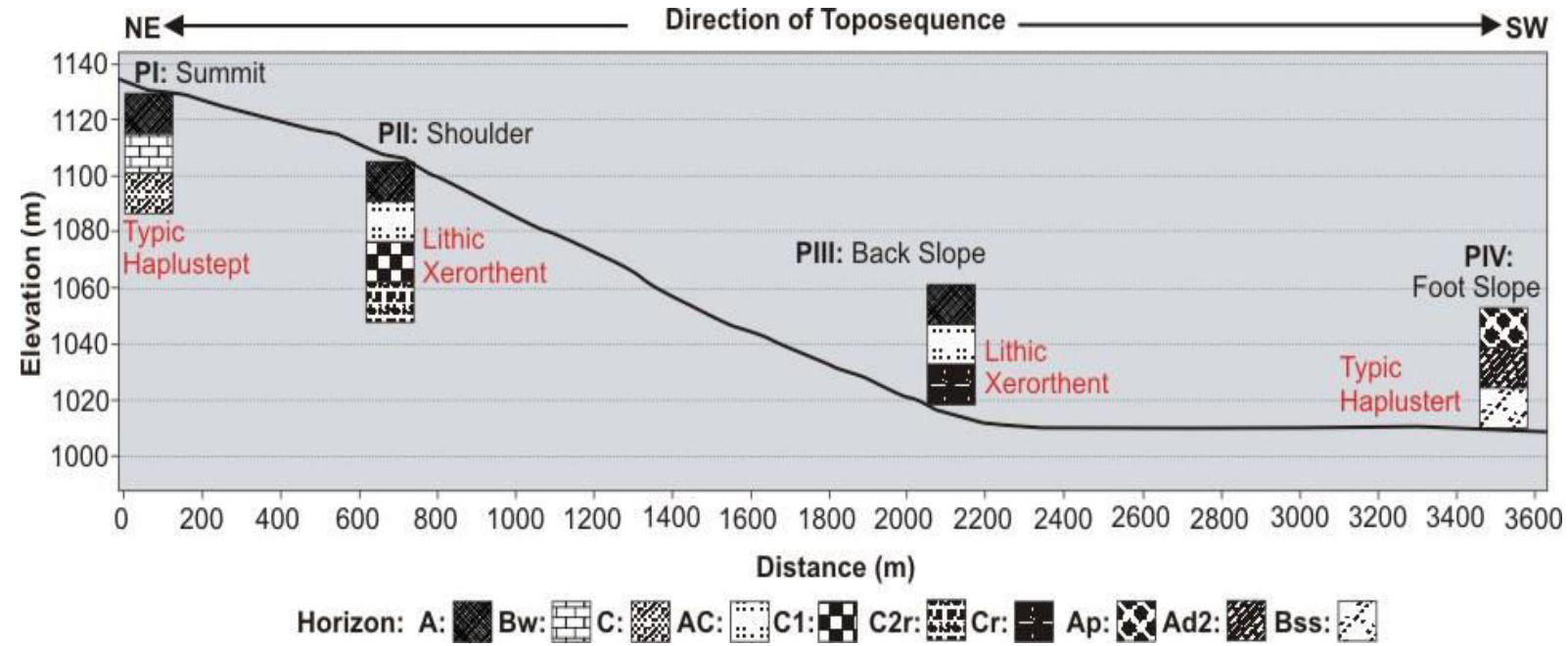

Figure 2. Direction of toposequence for soil profiles on lime stone parent material 


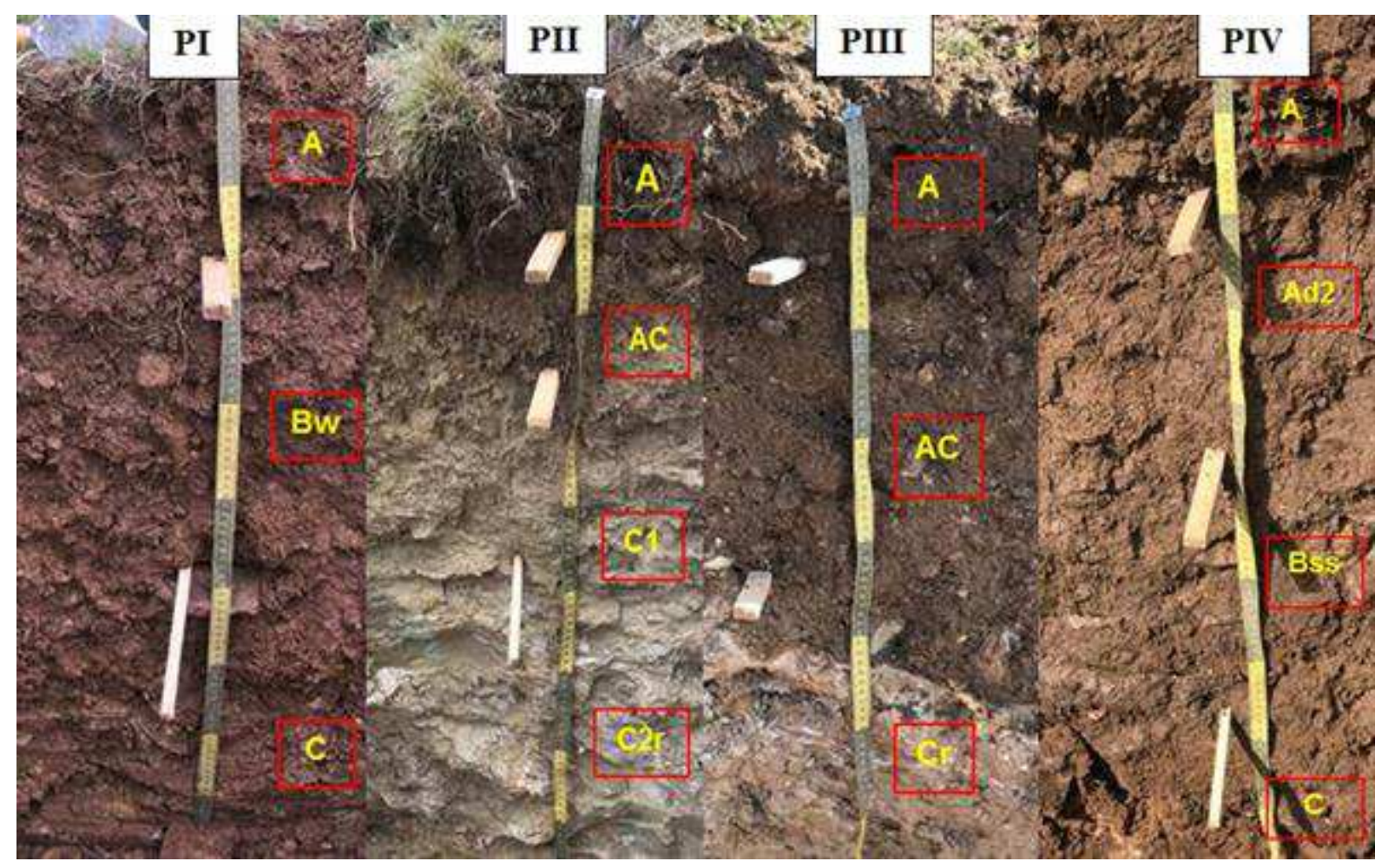

Figure 3. Soil profiles
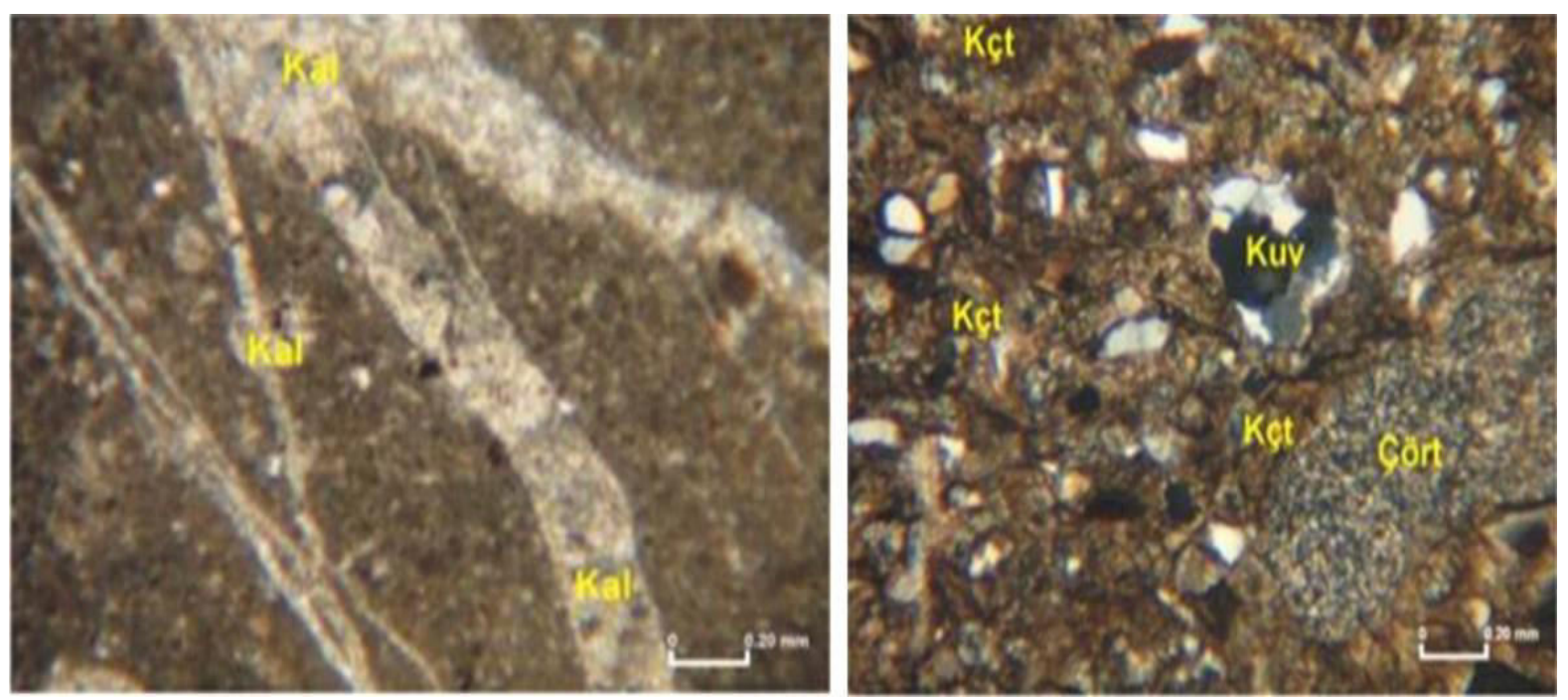

Figure 4. Rock microscope images (Kal: Calcite, Kçt: Limestone, Kuv: Quartz). 

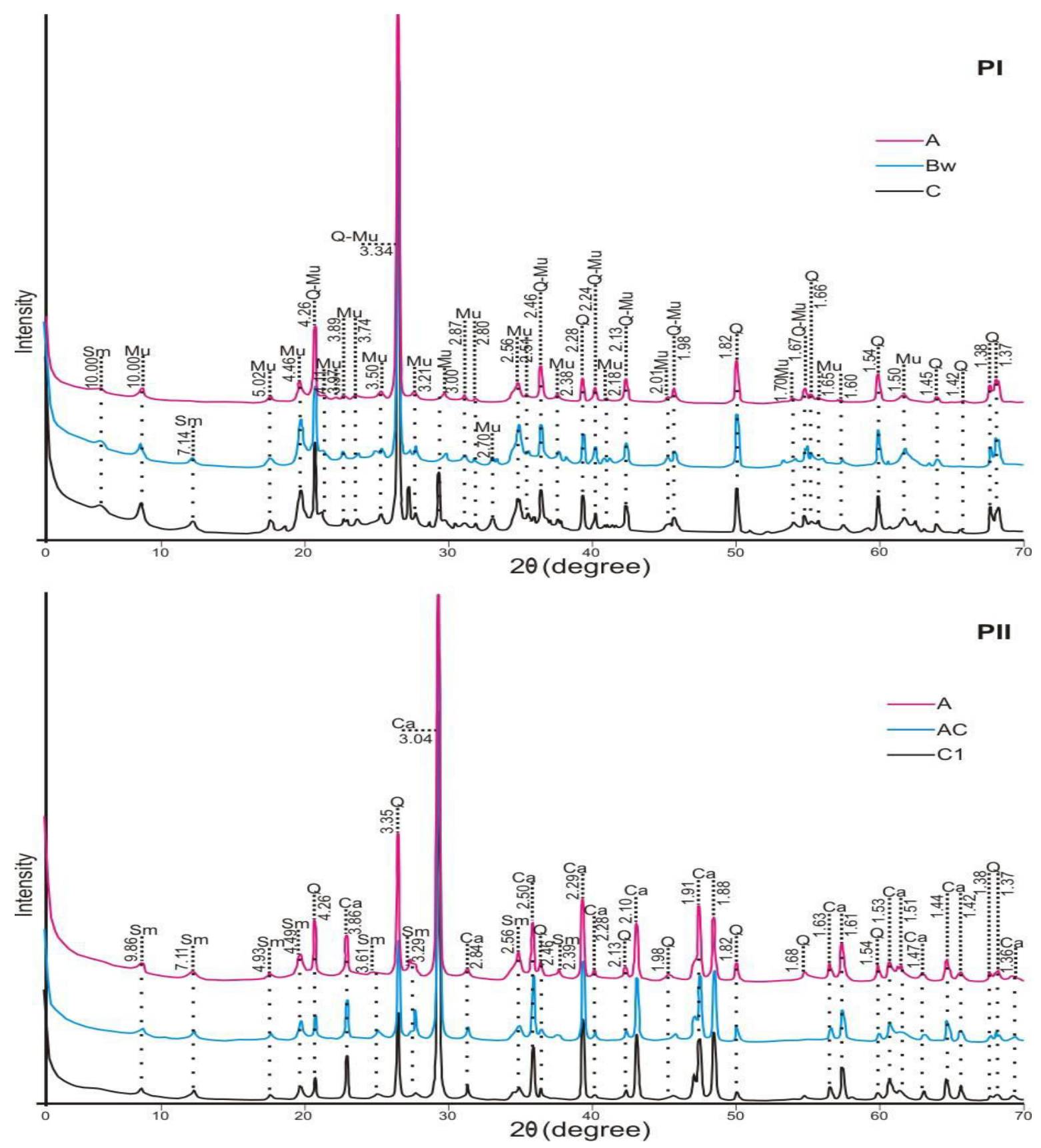

Figure 5. X-ray diffraction of primary clay minerals for PI and PII horizons 

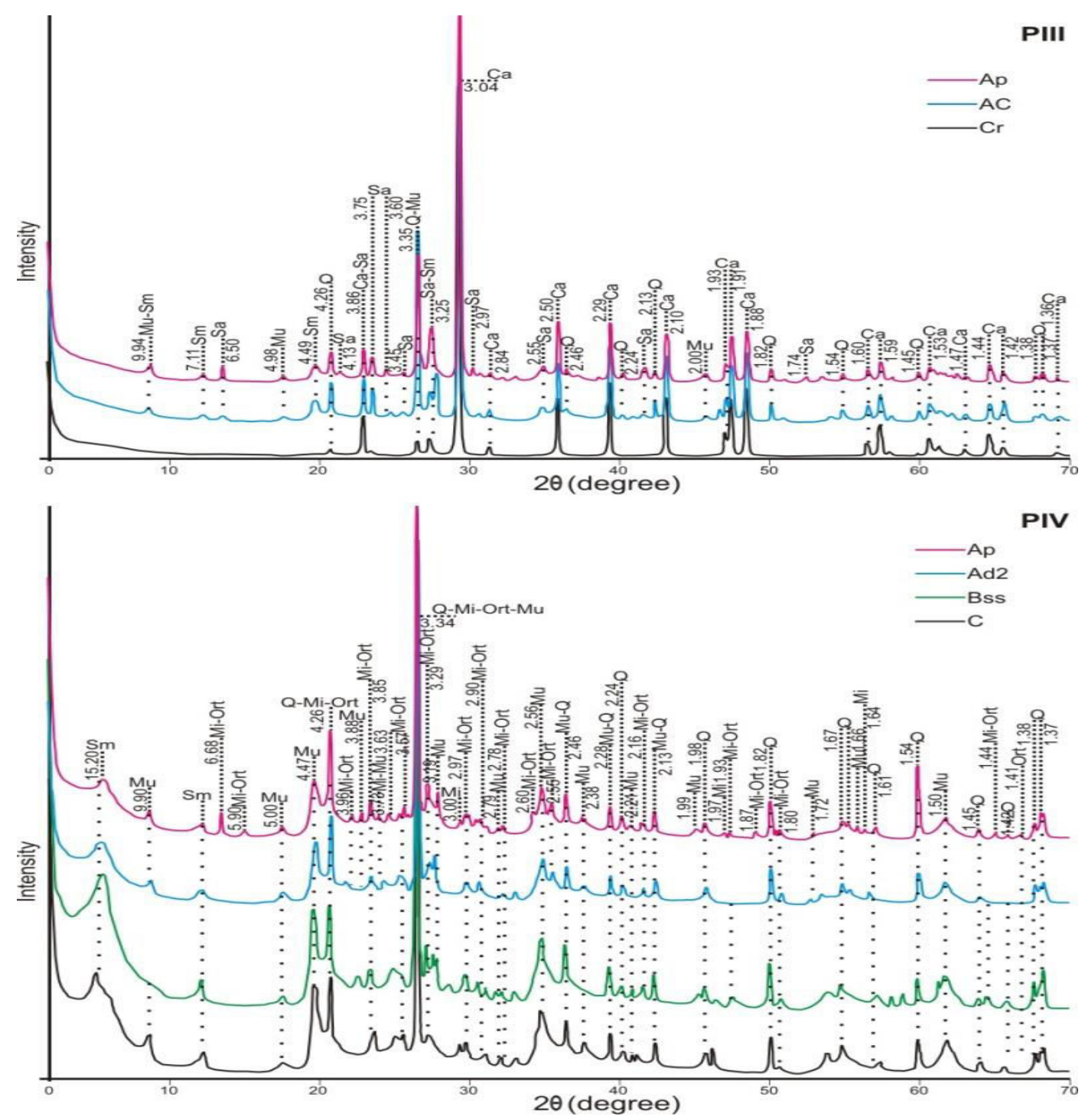

Figure 6. X-ray diffraction of primary clay minerals for PIII and PIV horizons 

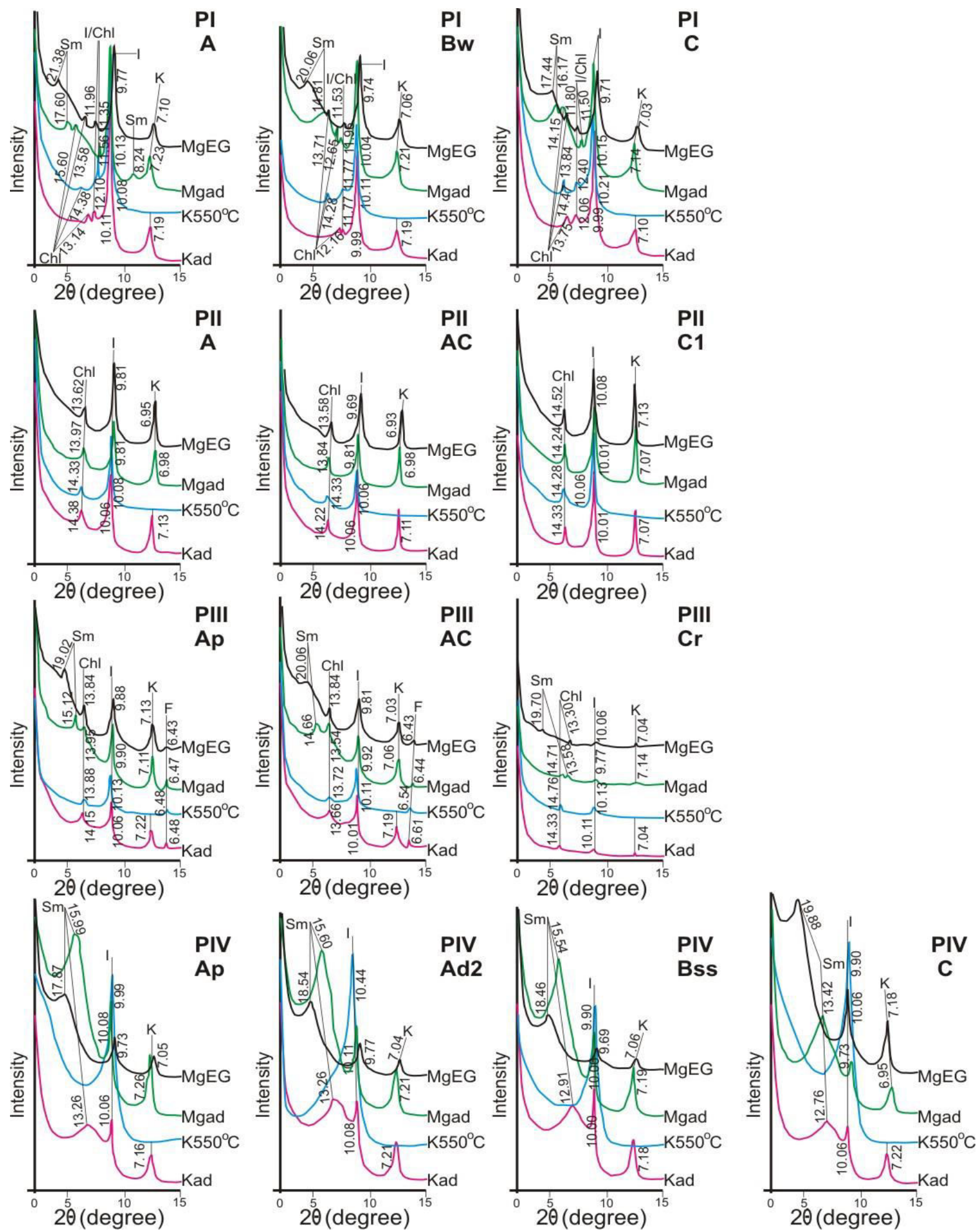

Figure 7. X-ray diffraction of clay fraction for profiles 
Table 1. Morphological description of soil profiles and their classification based on Soil Taxonomy (WRB, 2014)

\begin{tabular}{|c|c|c|}
\hline Depth & Horizon & Description \\
\hline \multicolumn{3}{|c|}{ PI- Summit-Typic Haplxerept-Cambisol } \\
\hline $0-18$ & A & $\begin{array}{l}\text { Yellowish brown (10YR5/4, Dry), Dark yellowish brown (10YR3/4, Wet); clay } \\
\text { loam; moderate, medium granular structure; sticky and plastic (wet), slightly } \\
\text { hard (dry); very few and very fine, common roots; low effervenscent; clear and } \\
\text { wavy boundary. }\end{array}$ \\
\hline $18-50$ & $\mathrm{Bw}$ & $\begin{array}{l}\text { Reddish grey (5YR5/2, Dry), Reddish brown (5YR4/4, Wet); clay; medium, } \\
\text { medium, subangular blocky structure; very sticky and very plastic (wet), hard } \\
\text { (dry); low effervenscent; very few, coarse and very fine roots, clear and wavy } \\
\text { boundary. }\end{array}$ \\
\hline $50+$ & $\mathrm{C}$ & $\begin{array}{l}\text { Reddish brown (5YR5/3, Dry), Reddish brown (5YR4/4, Wet); clay; massive } \\
\text { structure; very sticky and very plastic (wet), hard (dry); strong effervenscent; } \\
\text { limestone parent material. }\end{array}$ \\
\hline \multicolumn{3}{|c|}{ PII-Shoulder- Lithic Xereorthent-Lithic Mollic Leptosol } \\
\hline $0-12$ & A & $\begin{array}{l}\text { Brown (10YR5/3, Dry), Dark brown (10YR } 4 / 3 \text {, Wet); clay loam; moderate, } \\
\text { medium, granular structure; sticky and plastic (wet), slightly hard (dry); very } \\
\text { few, coarse and very fine roots; few and small stoniness; strong effervenscent; } \\
\text { clear and wavy boundary. }\end{array}$ \\
\hline $12-25$ & $\mathrm{AC}$ & $\begin{array}{l}\text { Light grey (10YR7/2, Dry), light yellowish brown (10YR6/4, Wet); silty clay; } \\
\text { moderate, medium and small granular and massif structure; sticky and plastic } \\
\text { (wet), slightly hard (dry); few and fine stoniness; strong effervenscent; gradual } \\
\text { and wavy boundary }\end{array}$ \\
\hline $25-46$ & $\mathrm{C} 1$ & $\begin{array}{l}\text { white (10YR8/1, Dry), Pale brown (10YR6/3, Wet); silty clay loam; massive } \\
\text { structure; sticky and plastic (wet), slightly hard (dry); strong effervenscent; } \\
\text { alternated lime stone }\end{array}$ \\
\hline $46+$ & $\mathrm{C} 2 \mathrm{r}$ & Limestone parent material \\
\hline \multicolumn{3}{|c|}{ PIII- Backslope- Lithic Xereorthent - Lithic Leptosol } \\
\hline $0-19$ & A & $\begin{array}{l}\text { Greyish brown (10YR5/2, Dry), dark brown (10YR3/3, Wet); clay loam; } \\
\text { moderate, medium and small granular structure; sticky and plastic (wet), slightly } \\
\text { hard (dry); medium and very fine roots; strong effervenscent; clear and wavy } \\
\text { boundary. }\end{array}$ \\
\hline $19-53$ & $\mathrm{AC}$ & $\begin{array}{l}\text { Pale brown (10YR6/3, Dry), light yellowish brown (10YR6/4, wet); clay; } \\
\text { moderate, medium, granular and massive structure; sticky and plastic (wet), hard } \\
\text { (dry); strong effervenscent; few very fine roots; clear and abrupt boundary. }\end{array}$ \\
\hline $53+$ & $\mathrm{Cr}$ & $\begin{array}{l}\text { White (10YR } 8 / 1 \text {, Dry), Very pale brown (10YR } 8 / 3 \text {, Wet); massive structure; } \\
\text { strong effervenscent, lime stone and colluvial material }\end{array}$ \\
\hline \multicolumn{3}{|c|}{ PIV- Footslope - Typic Haplxertert- Haplic Vertisol } \\
\hline $0-20$ & A & $\begin{array}{l}\text { Dark reddish grey (5YR4/2, Dry), Dark reddish grey (5YR3/2, Wet); clay loam; } \\
\text { moderate and strong, medium granular structure; sticky and plastic (wet), hard } \\
\text { (dry); low few fine roots; low effervenscent; wavy and abrupt boundary }\end{array}$ \\
\hline $20-49$ & $\mathrm{Ad} 2$ & $\begin{array}{l}\text { Dark reddish grey (5YR4/2, Dry), Dark reddish grey (5YR3/2, Wet); clay; } \\
\text { moderate and strong, medium, granular structure; very sticky and very plastic } \\
\text { (wet), very hard (dry); effervenscent; clear and wavy boundary }\end{array}$ \\
\hline $49-78$ & Bss & $\begin{array}{l}\text { Dark reddish grey (5YR4/2, Dry), Dark reddish grey (5YR3/2, Wet); clay; } \\
\text { strong, medium, subangular structure; very sticky and very plastic (wet), very } \\
\text { hard (dry); common and small slickenside; effervenscent; clear and wavy } \\
\text { boundary. }\end{array}$ \\
\hline $78+$ & $\mathrm{C}$ & Marl-colluvial deposit parent material \\
\hline
\end{tabular}


Table 2.Some physical and chemical properties of soils

\begin{tabular}{|c|c|c|c|c|c|c|c|c|c|c|c|c|c|}
\hline $\begin{array}{c}\text { Profile } \\
\text { No }\end{array}$ & Horizon & $\mathrm{pH}$ & $\begin{array}{c}\mathrm{EC} \\
\mathrm{dS} \mathrm{m}^{-1}\end{array}$ & $\begin{array}{c}\mathrm{CaCO}_{3} \\
\%\end{array}$ & $\begin{array}{c}\mathrm{OM} \\
\%\end{array}$ & $\begin{array}{l}\mathrm{C} \\
\%\end{array}$ & $\begin{array}{l}\mathrm{Si} \\
\%\end{array}$ & $\begin{array}{l}\text { S } \\
\%\end{array}$ & \multicolumn{5}{|c|}{$\operatorname{cmol}(+) \mathrm{kg}^{-1}$} \\
\hline \multicolumn{14}{|c|}{ Summit-Typic Haplxerept-Cambisol } \\
\hline \multirow{3}{*}{$\mathrm{P}$} & $\mathrm{A}$ & 7.66 & 0.08 & 5.02 & 1.06 & 34.76 & 22.81 & 42.42 & 0.06 & 0.49 & 25.43 & 1.68 & 28.12 \\
\hline & Bw & 7.87 & 0.08 & 7.48 & 0.83 & 54.91 & 15.76 & 29.32 & 0.17 & 0.35 & 26.52 & 5.95 & 30.23 \\
\hline & $\mathrm{C}$ & 8.10 & 0.18 & 22.20 & 0.36 & 42.17 & 14.63 & 43.18 & 0.24 & 0.25 & 33.91 & 7.48 & 31.17 \\
\hline \multicolumn{14}{|c|}{ Shoulder- Lithic Xereorthent-Lithic Mollic Leptosol } \\
\hline \multirow{2}{*}{ PII } & $\mathrm{A}$ & 8.03 & 0.15 & 16.40 & 1.40 & 23.27 & 31.88 & 44.83 & 0.05 & 0.61 & 37.31 & 0.72 & 19.93 \\
\hline & $\mathrm{C}$ & 8.23 & 0.10 & 22.71 & 0.75 & 13.89 & 27.45 & 58.64 & 0.03 & 0.17 & 33.55 & 0.49 & 12.94 \\
\hline \multicolumn{14}{|c|}{ Backslope- Lithic Xereorthent - Lithic Leptosol } \\
\hline \multirow{3}{*}{ PIII } & Ap & 7.97 & 0.17 & 24.76 & 1.72 & 38.37 & 27.20 & 34.48 & 0.06 & 0.05 & 30.56 & 0.39 & 28.06 \\
\hline & $\mathrm{AC}$ & 8.01 & 0.17 & 37.49 & 0.66 & 41.38 & 21.00 & 37.62 & 0.04 & 0.98 & 39.63 & 1.05 & 31.31 \\
\hline & $\mathrm{Cr}$ & 8.10 & 0.18 & 41.14 & 0.78 & 35.95 & 17.80 & 46.27 & 0.04 & 0.53 & 36.50 & 1.01 & 29.44 \\
\hline \multicolumn{14}{|c|}{ Footslope - Typic Haplxertert- Haplic Vertisol } \\
\hline \multirow{4}{*}{ PIV } & $\mathrm{A}$ & 7.78 & 0.12 & 15.98 & 4.11 & 31.82 & 32.30 & 35.92 & 0.07 & 0.05 & 27.24 & 0.46 & 28.21 \\
\hline & $\operatorname{Ad} 2$ & 7.88 & 0.10 & 17.69 & 2.43 & 41.41 & 28.00 & 30.64 & 0.02 & 0.76 & 33.34 & 0.58 & 32.02 \\
\hline & Bss & 7.86 & 0.37 & 16.46 & 0.64 & 45.03 & 27.10 & 27.85 & 0.02 & 0.12 & 30.28 & 0.22 & 28.24 \\
\hline & $\mathrm{C}$ & 8.01 & 0.15 & 17.03 & 0.61 & 56.19 & 16.40 & 27.38 & 0.07 & 1.08 & 40.17 & 4.37 & 30.53 \\
\hline
\end{tabular}

OM: organic matter, C:clay, Si: silt, S:sand, CEC: Cation exchange capacity

Table 3. Primary minerals and densities of soils formed on different parent rock

\begin{tabular}{cllcccccccc}
\hline Pedon & Horizon & $\mathrm{a}$ & $\mathrm{b}$ & $\mathrm{c}$ & $\mathrm{d}$ & $\mathrm{e}$ & $\mathrm{i}$ & $\mathrm{s}$ & $\mathrm{p}$ \\
\hline \multirow{3}{*}{$\mathrm{PI}$} & $\mathrm{A}$ & - & - & - & ++++ & +++ & - & + & - \\
& $\mathrm{BW}$ & - & - & - & ++++ & ++ & - & + & - \\
& $\mathrm{C}$ & - & - & - & ++++ & ++ & - & + & - \\
\hline \multirow{2}{*}{ PII } & $\mathrm{A}$ & ++ & - & - & ++++ & +++ & - & + & ++ \\
& $\mathrm{AC}$ & ++ & - & - & ++++ & ++ & - & + & + \\
\hline \multirow{3}{*}{ PIII } & $\mathrm{Ap}$ & +++ & ++ & - & ++ & ++ & - & + & - \\
& $\mathrm{AC}$ & ++++ & + & - & ++ & + & - & + & - \\
& $\mathrm{Cr}$ & ++++ & + & - & + & + & - & + & - \\
\hline \multirow{5}{*}{ PIV } & $\mathrm{A}$ & + & - & +++ & ++++ & ++ & ++ & + & - \\
& $\mathrm{Ad} 2$ & + & - & ++ & ++++ & +++ & ++ & + & - \\
& $\mathrm{Bss}$ & $\mathrm{C}$ & + & - & ++ & ++++ & +++ & +++ & + & - \\
& $\mathrm{C}$ & + & - & ++ & ++++ & +++ & +++ & + & - \\
\hline
\end{tabular}

Abundance: ++++ Very Abundant, +++ Much, ++ Medium, + Low; Minerals: a: Calcite, b: Sanidine, c: Microcline, d: Quartz, e: Muscovite, i: Orthoclase, s: Montmorillonite, p: Kristobalite 
Table 4. Distribution of clay minerals in profiles

\begin{tabular}{|c|c|c|c|c|c|c|c|c|c|c|c|}
\hline \multirow{2}{*}{ Profile } & \multirow{2}{*}{ Horizon } & \multicolumn{2}{|c|}{ Smectite } & \multicolumn{2}{|c|}{ İllite } & \multicolumn{2}{|c|}{ Kaolinite } & \multicolumn{2}{|c|}{ Chlorite } & \multicolumn{2}{|c|}{ İllite- Chlorite } \\
\hline & & A & $\mathrm{C}$ & A & $\mathrm{C}$ & A & $\mathrm{C}$ & A & $\mathrm{C}$ & $\mathrm{A}$ & $\mathrm{C}$ \\
\hline \multirow[t]{3}{*}{ PI } & A & ++ & + & ++++ & ++++ & +++ & +++ & + & + & + & + \\
\hline & $\mathrm{Bw}$ & +++ & + & ++++ & ++++ & ++ & ++ & + & + & + & + \\
\hline & $\mathrm{C}$ & +++ & ++ & ++++ & ++++ & ++ & +++ & + & + & + & + \\
\hline \multirow[t]{2}{*}{ PII } & A & ++ & ++ & ++++ & ++++ & +++ & ++++ & + & ++ & - & - \\
\hline & $\mathrm{AC}$ & ++ & + & ++++ & ++++ & +++ & ++++ & + & + & - & - \\
\hline \multirow{3}{*}{ PIII } & Ap & + & + & ++++ & ++++ & +++ & ++++ & ++ & ++ & - & - \\
\hline & $\mathrm{AC}$ & ++ & + & ++++ & ++++ & +++ & ++++ & + & ++ & - & - \\
\hline & $\mathrm{Cr}$ & + & + & ++ & + & + & + & + & + & - & - \\
\hline \multirow{4}{*}{ PIV } & A & ++++ & +++ & +++ & ++++ & ++ & ++ & - & - & - & - \\
\hline & $\mathrm{Ad} 2$ & ++++ & ++++ & +++ & ++++ & ++ & ++ & - & - & - & - \\
\hline & Bss & ++++ & ++++ & +++ & ++++ & ++ & ++ & - & - & - & - \\
\hline & $\mathrm{C}$ & +++ & ++++ & ++++ & ++++ & ++ & ++ & - & - & - & - \\
\hline
\end{tabular}

A: Abundance: ++++ Very Abundant, +++ Much, ++ Medium, + Low; C: Crystallinity: ++++ Very Good, +++ Good, ++ Fair, + Bad

Table 5. Fragmentation-weathering indexes of soil profiles

Profile

Horizon

CIA

CIW

PIA $\quad \mathrm{Baz} / \mathrm{R}_{2} \mathrm{O}_{3}$

\begin{tabular}{cccccc}
\hline & $\mathrm{A}$ & $73.12 \mathrm{a}$ & $89.20 \mathrm{a}$ & $55.09 \mathrm{a}$ & $0.45 \mathrm{c}$ \\
$\mathrm{PI}$ & $\mathrm{Bw}$ & $77.71 \mathrm{a}$ & $90.35 \mathrm{a}$ & $63.72 \mathrm{a}$ & $0.38 \mathrm{c}$ \\
& $\mathrm{C}$ & $58.96 \mathrm{~b}$ & $65.38 \mathrm{ab}$ & $49.15 \mathrm{a}$ & $0.71 \mathrm{c}$ \\
\hline \multirow{2}{*}{$\mathrm{PII}$} & $\mathrm{A}$ & $43.36 \mathrm{~b}$ & $47.84 \mathrm{~b}$ & $34.00 \mathrm{~b}$ & $1.23 \mathrm{bc}$ \\
& $\mathrm{C}$ & $40.35 \mathrm{~b}$ & $44.08 \mathrm{~b}$ & $31.88 \mathrm{~b}$ & $1.38 \mathrm{bc}$ \\
\hline \multirow{3}{*}{$\mathrm{PIII}$} & $\mathrm{Ap}$ & $16.78 \mathrm{c}$ & $17.58 \mathrm{c}$ & $12.24 \mathrm{c}$ & $4.16 \mathrm{~b}$ \\
& $\mathrm{AC}$ & $15.54 \mathrm{c}$ & $16.22 \mathrm{c}$ & $11.30 \mathrm{c}$ & $4.55 \mathrm{~b}$ \\
& $\mathrm{Cr}$ & $4.47 \mathrm{~d}$ & $4.54 \mathrm{~d}$ & $3.00 \mathrm{~d}$ & $17.53 \mathrm{a}$ \\
\hline \multirow{3}{*}{$\mathrm{PIV}$} & $\mathrm{A}$ & $67.96 \mathrm{a}$ & $78.61 \mathrm{a}$ & $54.41 \mathrm{a}$ & $0.58 \mathrm{c}$ \\
& $\mathrm{Ad} 2$ & $70.22 \mathrm{a}$ & $80.05 \mathrm{a}$ & $57.94 \mathrm{a}$ & $0.54 \mathrm{c}$ \\
& $\mathrm{Bss}$ & $72.57 \mathrm{a}$ & $82.06 \mathrm{a}$ & $61.01 \mathrm{a}$ & $0.50 \mathrm{c}$ \\
& $\mathrm{C}$ & $74.32 \mathrm{a}$ & $83.10 \mathrm{a}$ & $63.76 \mathrm{a}$ & $0.46 \mathrm{c}$ \\
\hline
\end{tabular}

* Interhorizontal variability showed significant variation at $\mathrm{p}<0.01$ 
Table 6. Mass transport function values $(\tau)$ and mass gains $\left(\mathrm{gr} \mathrm{cm}^{-2}\right)$ for some elements in the profiles

\begin{tabular}{|c|c|c|c|c|c|c|c|c|c|c|c|c|c|c|c|}
\hline \multirow{2}{*}{ Profile } & \multirow{2}{*}{ Horizon } & \multicolumn{2}{|c|}{$\mathrm{Si}$} & \multicolumn{2}{|c|}{$\mathrm{Al}$} & \multicolumn{2}{|c|}{$\mathrm{Fe}$} & \multicolumn{2}{|c|}{$\mathrm{Na}$} & \multicolumn{2}{|c|}{$\mathrm{K}$} & \multicolumn{2}{|c|}{$\mathrm{Mg}$} & \multicolumn{2}{|c|}{$\mathrm{Ca}$} \\
\hline & & $(\tau)$ & Mjflux & $(\tau)$ & Mjflux & $(\tau)$ & Mjflux & $(\tau)$ & Mjflux & $(\tau)$ & Mjflux & $(\tau)$ & Mjflux & $(\tau)$ & Mjflux \\
\hline \multirow{4}{*}{ PI } & A & 0.16 & 24.60 & -0.22 & -10.91 & -0.35 & -6.58 & -0.42 & -0.70 & 0.15 & 1.11 & -0.30 & -1.25 & -0.87 & -10.99 \\
\hline & $\mathrm{Bw}$ & 0.14 & 30.91 & 0.00 & 0.20 & -0.13 & -3.64 & -0.38 & -0.93 & 0.08 & 0.93 & -0.12 & -0.78 & -0.85 & -15.95 \\
\hline & $\mathrm{C}$ & 0.00 & 0.00 & 0.00 & 0.00 & 0.00 & 0.00 & 0.00 & 0.00 & 0.00 & 0.00 & 0.00 & 0.00 & 0.00 & 0.00 \\
\hline & Total & & 55.51 & & -10.71 & & -10.22 & & -1.63 & & 2.04 & & -2.02 & & -26.95 \\
\hline \multirow{4}{*}{ PII } & A & -0.24 & -11.17 & -0.24 & -4.33 & -0.05 & -0.23 & 0.98 & 0.24 & -0.21 & -0.84 & -0.21 & -0.54 & -0.49 & -35.42 \\
\hline & $\mathrm{AC}$ & -0.22 & -9.26 & -0.15 & -2.45 & -0.08 & -0.31 & 0.17 & 0.04 & -0.12 & -0.44 & -0.16 & -0.37 & -0.26 & -17.56 \\
\hline & C1 & 0.00 & 0.00 & 0.00 & 0.00 & 0.00 & 0.00 & 0.00 & 0.00 & 0.00 & 0.00 & 0.00 & 0.00 & 0.00 & 0.00 \\
\hline & Total & & -20.44 & & -6.78 & & -0.54 & & 0.28 & & -1.28 & & -0.91 & & -52.98 \\
\hline \multirow{4}{*}{ PIII } & Ap & -0.09 & -7.44 & -0.02 & -0.59 & 0.23 & 1.52 & -0.24 & -0.53 & -0.20 & -1.47 & -0.16 & -0.75 & -0.79 & -217.23 \\
\hline & $\mathrm{AC}$ & -0.09 & -13.05 & -0.01 & -0.27 & 0.20 & 2.37 & -0.23 & -0.87 & -0.18 & -2.30 & -0.19 & -1.59 & -0.76 & -366.52 \\
\hline & $\mathrm{Cr}$ & 0.00 & 0.00 & 0.00 & 0.00 & 0.00 & 0.00 & 0.00 & 0.00 & 0.00 & 0.00 & 0.00 & 0.00 & 0.00 & 0.00 \\
\hline & Total & & -20.49 & & -0.86 & & 3.89 & & -1.40 & & -3.76 & & -2.34 & & -583.74 \\
\hline \multirow{5}{*}{ PIV } & $\mathrm{A}$ & 0.12 & 15.72 & -0.11 & -5.07 & -0.09 & -1.36 & 0.98 & 0.64 & 0.25 & 1.45 & 0.01 & 0.04 & 0.08 & 0.37 \\
\hline & $\operatorname{Ad} 2$ & 0.10 & 19.52 & -0.05 & -3.88 & -0.06 & -1.41 & 1.30 & 1.36 & 0.16 & 1.52 & 0.03 & 0.19 & 0.00 & 0.03 \\
\hline & Bss & 0.13 & 24.81 & 0.02 & 1.14 & 0.00 & 0.04 & 0.72 & 0.73 & 0.14 & 1.26 & 0.07 & 0.48 & 0.01 & 0.06 \\
\hline & $\mathrm{C}$ & 0.00 & 0.00 & 0.00 & 0.00 & 0.00 & 0.00 & 0.00 & 0.00 & 0.00 & 0.00 & 0.00 & 0.00 & 0.00 & 0.00 \\
\hline & Total & & 60.05 & & -7.80 & & -2.73 & & 2.73 & & 4.24 & & 0.72 & & 0.45 \\
\hline
\end{tabular}

Table 7. Some soil physical properties of the profiles

\begin{tabular}{cccccccc}
\hline \multirow{2}{*}{ Profile } & Horizon & $\begin{array}{c}\text { AS } \\
\%\end{array}$ & $\begin{array}{c}\text { FC } \\
\%\end{array}$ & $\begin{array}{c}\text { WP } \\
\%\end{array}$ & $\begin{array}{c}\text { AWC } \\
\%\end{array}$ & $\begin{array}{c}\text { BD } \\
\mathrm{gr} \mathrm{cm}^{-3}\end{array}$ & $\begin{array}{c}\text { P } \\
\%\end{array}$ \\
\hline \multirow{2}{*}{ PI } & A & 59.99 & $33.1 \mathrm{~b}$ & $21.0 \mathrm{~b}$ & 12.1 & 1.51 & $42.91 \mathrm{a}$ \\
& $\mathrm{Bw}$ & 63.74 & $44.4 \mathrm{a}$ & $32.6 \mathrm{a}$ & 11.8 & 1.47 & $43.67 \mathrm{a}$ \\
& $\mathrm{C}$ & 57.68 & $37.1 \mathrm{a}$ & $25.4 \mathrm{~b}$ & 11.7 & - & - \\
\hline \multirow{2}{*}{ PII } & $\mathrm{A}$ & 54.99 & $22.17 \mathrm{c}$ & $11.23 \mathrm{c}$ & 10.9 & 1.53 & $34.91 \mathrm{~b}$ \\
& $\mathrm{C}$ & 51.74 & $19.32 \mathrm{~d}$ & $11.02 \mathrm{c}$ & 8.30 & - & - \\
\hline \multirow{2}{*}{ PIII } & $\mathrm{Ap}$ & 61.25 & $35.5 \mathrm{~b}$ & $21.0 \mathrm{~b}$ & 14.5 & 1.46 & $45.43 \mathrm{a}$ \\
& $\mathrm{AC}$ & 60.45 & $39.1 \mathrm{a}$ & $24.5 \mathrm{~b}$ & 14.6 & 1.5 & $43.99 \mathrm{a}$ \\
& $\mathrm{Cr}$ & 60.14 & $38.6 \mathrm{a}$ & $23.5 \mathrm{~b}$ & 15.1 & - & - \\
\hline \multirow{3}{*}{ PIV } & $\mathrm{A}$ & 57.42 & $35.0 \mathrm{~b}$ & $21.1 \mathrm{~b}$ & 13.9 & 1.37 & $48.67 \mathrm{a}$ \\
& $\mathrm{Ad} 2$ & 60.45 & $41.4 \mathrm{a}$ & $29.0 \mathrm{a}$ & 12.4 & 1.43 & $46.51 \mathrm{a}$ \\
& $\mathrm{Bss}$ & 62.87 & $43.1 \mathrm{a}$ & $29.7 \mathrm{a}$ & 13.4 & 1.41 & $47.23 \mathrm{a}$ \\
& $\mathrm{C}$ & 59.25 & $48.5 \mathrm{a}$ & $35.4 \mathrm{a}$ & 13.1 & - & - \\
\hline
\end{tabular}

AS:aggregate stability, FC: Field capacity, WP:wilting point, AWC:available water content, BD:bulk density, P:porosity

Table 8 . Correlation between physiography and some soil properties

\begin{tabular}{lccccccccc}
\hline & $\mathrm{C}$ & $\mathrm{Si}$ & $\mathrm{S}$ & $\mathrm{AS}$ & $\mathrm{FC}$ & $\mathrm{Wp}$ & $\mathrm{AWC}$ & $\mathrm{BD}$ & $\mathrm{P}$ \\
\hline Physiography & .165 & $.376^{*}$ & $-.466^{*}$ & .247 & $.373^{*}$ & .296 & $.506^{*}$ & .077 & .145 \\
\hline Smectite & .336 & .158 & $-.538^{*}$ & .155 & $.391^{*}$ & $.469^{*}$ & -.095 & .183 & .297 \\
\hline Illite & .013 & -.116 & .060 & -.263 & -.231 & -.142 & $-.477^{*}$ & .118 & .042 \\
\hline Kaolinite & $-.438^{*}$ & $.407^{*}$ & .284 & -.345 & $-.575^{*}$ & $-.555^{*}$ & $-.390^{*}$ & $.420^{*}$ & .299 \\
\hline $\begin{array}{l}\text { *p<0.05, AS: Aggregate stability, FC: Field Capacity, WP: Wilting Point, AWC: Available water content, BD: } \\
\text { Bulk density, P: porosity }\end{array}$
\end{tabular}

